(C) 2020. This manuscript version is made available under the CC-BY-NC-ND 4.0 license http://creativecommons.org/ licenses/by-nc-nd/4.0/

\title{
Detrital zircon and monazite track the source of Mesozoic sediments in Kutch to rocks of Late Neoproterozoic and Early Palaeozoic orogenies in northern India
}

\author{
Angana Chaudhuri ${ }^{1}$, Kaushik Das ${ }^{2,4}$, ${ }^{*}$ Santanu Banerjee ${ }^{1}$ and Ian C.W. Fitzsimons ${ }^{3}$ \\ ${ }^{1}$ Department of Earth Sciences, Indian Institute of Technology Bombay, Powai, Mumbai-400076, \\ India \\ ${ }^{2}$ Department of Earth and Planetary Systems Science, Graduate School of Science, Hiroshima \\ University, 1-3-1 Kagamiyama, Higashi-Hiroshima, Hiroshima, 739-8526, Japan \\ ${ }^{3}$ School of Earth and Planetary Sciences, Curtin University, Perth WA 6845, Australia \\ ${ }^{4}$ Hiroshima Institute of Plate Convergence Area Research, Hiroshima, 739-8526
}

Corresponding author: santanu@iitb.ac.in

\begin{abstract}
Detrital zircon and monazite dating of clastic rocks in the Mesozoic Kutch Basin at the western continental margin of India reveals predominant sediment derivation from rocks of Neoproterozoic Pan-African orogeny, followed by those of Cambro-Ordovician Bhimphedian (or Kurgiakh) orogeny in Himalayan region and 850-1000 Ma rocks, with subordinate input from rocks of 700$800 \mathrm{Ma}, 1500-1600 \mathrm{Ma}, 2400-2500 \mathrm{Ma}$ and 2800-3300 Ma. This finding refutes the existing idea regarding the predominant Mesoproterozoic source inferred for this basin. The dominance of southwesterly palaeocurrent data of Mesozoic rocks in Kutch Basin rules out sediment supply from south or west. Th/U ratios of detrital zircon grains indicate predominantly magmatic and subordinately metamorphic source rock. Petrographic data, particularly the QFR plot supports this interpretation of source rock. Rocks belonging to the Pan-African orogeny are poorly exposed in northwestern India while isolated outcrops of peralkaline granites in the Himalayan region bear testimony of the Bhimphedian orogeny. While the paucity of records of the Pan-African orogeny in western India possibly relates to either burial under the Deccan Flood Basalts or extensive erosion during Mesozoic greenhouse climate, the dearth of rocks of Bhimphedian orogeny results from its occurrence along the present-day Himalayan thrust belt. The absence of detrital zircon grains younger than $458 \mathrm{Ma}$ indicates that post-Ordovician tectono-thermal events skipped the source area. The large gap between youngest detrital zircon and the depositional age of the Mesozoic sediments, suggests long-distance sediment transport as well as sediment recycling. This study, therefore,
\end{abstract}


indicates the existence of widespread younger magmatic rocks to the north during the deposition of Mesozoic of Kutch.

Keywords:

Detrital zircon geochronology, U-Pb dating, U-Th-total $\mathrm{Pb}$ monazite, Pan-African Orogeny, Bhimphedian orogeny, Kutch Basin

\section{Introduction}

Break-up and drift of landmasses engender rift basins (Kreuser, 1995; Nikishin et al., 1996; Biswas, 1999; Wang and Li, 2003; Stephenson et al., 2006; De Waele et al., 2008; Cawood et al., 2016). These basins act as receptacles of sediments derived from neighboring orogenic belts. These sediment piles below the base level of erosion thus hold the evolutionary record of past orogenic belts and thereby form a valuable record of plate tectonic reconstruction (Dickinson and Suczek, 1979; Dickinson, 1988). The Kutch rift basin, at the western continental margin of India originates by the break-up of Gondwana in the Late Triassic to Early Jurassic (Biswas, 1982, 1987, 1999, 2005). As the western part of the Indian subcontinent remained juxtaposed with Madagascar and Seychelles during the Mesozoic (Torsvik et al., 1998; Collier et al., 2008), the possible hinterlands of this basin include several present-day landmasses, covering a wide time-span. Cratons and orogenic belts of Archean to Mesoproterozoic age occur in western India. Younger Late Neoproterozoic orogenic belts rarely crop out despite their proximity to Madagascar at the time of orogenesis (Santosh and Drury, 1988; Santosh et al., 1989; Choudhary et al., 1984, 1992; Kriegsman, 1995; Rathore et al., 1999; Yoshida et al., 2003). The Early Palaeozoic orogenic rocks occur as scattered outcrops in the axial zones of the Himalayan fold belt, resulting from the folding of Andean-type northern margin of the Indian subcontinent post Gondwana break-up (Cawood et al., 2007; Myrow et al., 2016).

A consensus exists that the detrital sediments of the Kutch basin were derived from the Aravalli highlands to the east and the Nagar Parkar ridge to the north, which is largely based on the southwesterly palaeocurrent data of Mesozoic rocks (Biswas, 1999, 2005; Ahmad and Bhat, 2006; Ramakrishnan and Vaidyanathan, 2008; Ahmad et al., 2014; Mandal et al., 2016; Khan et al., 2017a). On the basis of sandstone petrography and heavy mineral chemistry Chaudhuri et al. (2018, 2020) recently suggested mixed felsic and mafic sources for the Mesozoic sediments of Kutch, along with polycyclic detrital zircon grains. The objectives of the current work are: a) to unravel the exact ages of source rocks of siliciclastics of the Mesozoic Kutch Basin, b) relate the age of 
sediment sources to possible source areas and c) discuss the paleotectonic reconstruction of areas around the Kutch basin. We present petrographic and palaeocurrent data followed by results of detrital monazite and zircon geochronology and $\mathrm{Th} / \mathrm{U}$ ratios of zircon grains from selected sandstone and conglomerate samples.

\section{Geological Background}

The Kutch Basin at the western continental margin of India formed by rifting initiated during the Late Triassic by the reactivation of primordial faults in the Precambrian Aravalli-Delhi fold belt (Biswas, 1982, 1987, 1993, 2005). Nearly $3000 \mathrm{~m}$ of siliciclastic and carbonate sediment pile was deposited between the Late Triassic and the Early Cretaceous during the rifting and India's northward drift following Gondwana break-up (Biswas, 1982, 1987). During the post-rift phase, the basin accumulated mixed carbonate-siliciclastic sediments over the Cenozoic period (Biswas, 1981). The Kutch basin is bounded by the Nagar Parkar Ridge to the north, Kathiawar uplift to the south, Radhanpur-Barmer Arch to the east and continental shelf to the west (Fig. 1c). Mesozoic exposures of this basin occur within several fault-controlled uplifts, viz. Nagar Parkar Uplift, Island Belt Uplift (comprising isolated island-like uplifts - Patcham, Khadir, Bela and Chorar), Wagad Uplift and Kutch Mainland Uplift (Biswas, 1980, 2005) (Fig. 1c). Igneous intrusions such as laccoliths, plugs, sills and dike swarms occur along these tectonized zones resulting in a series of asymmetric domes at Zara, Jumara, Nara, Keera, Jhura and Habo (Biswas 1987, 2005; Ray et al., 2006; Karmalkar et al., 2009, 2014; Kshirsagar et al., 2011). These domes expose older rocks in their core, while the younger rocks occur on their flanks. The Kutch Mainland, covering the largest part of the preserved basin, exposes almost the entire Mesozoic rock record along an NW-SE trending chain of domal outcrops (Alberti et al., 2013).

The Mesozoic succession of this region comprises Jhurio, Jhumara, Jhuran and Bhuj formations (Biswas, 1987) in order of upward succession (Fig. 1a). Basement rocks are absent in the Kutch Mainland. However, the Cheriyabet Conglomerate in Khadir Island represents the base of Mesozoic succession, which passes upward to Bathonian sedimentary rocks (Biswas and Deshpande, 1968). This conglomerate has angular to slightly rounded clasts with long dimension up to $16 \mathrm{~cm}$ (Fig. 2a). The Bathonian Jhurio Formation mainly consists of limestones and shales with minor occurrences of sandstones (Fig. 2b). The overlying Jhumara Formation consists primarily of shale with minor and sandstones at the bottom overlain by a dominantly carbonate succession with some argillaceous rocks towards the top (Fig. 2c). Based on lithology and fossil content previous workers considered a shelf depositional setting for Jhurio and Jhumara formations (Figs. 2b, 2c) (Fürsich et al., 1991, 2004). Alternations between shale and wavy laminated sandstone dominate the 
Jhuran Formation (Fig. 2d). It represents a storm-dominated, overall prograding upward siliciclastic succession (Arora et al., 2015, 2017; Chaudhuri, 2019). The youngest Bhuj Formation unconformably overlies the Jhuran Formation and consists primarily of sandstone and some shale (Biswas, 1977, 1981, 1983; Bansal et al., 2017; Desai and Biswas, 2018). It represents a thick sequence of megadelta system punctuated by two transgressive events (Desai and Biswas, 2018). Mandal et al. (2016) recognized the establishment of an estuarine system at the lower part of the Bhuj Formation related to the transgressive event, followed upward by fluvial sandstones (Fig. 2e). Paleocurrent attributes are rare in the lower two carbonate- and finer clast dominated formations, but in the upper two clastic-dominated formations, they depict a general southwesterly direction (Biswas, 1987, 1999, 2005; Mandal et al., 2016; Arora, 2017; Desai and Biswas, 2018; Chaudhuri, 2019). Thicknesses of all the constituent formations increase towards west and southwest (Biswas, 1987, 1999, 2005; Desai and Biswas, 2018).

\section{Methodology}

Sandstone samples for the present investigation were collected from Zara, Nirona, Palara, Habo, Tapkeshwar, Gangeshwar, and Bhuj in Kutch mainland (Fig. 1c). Thin sections of these sandstones were prepared using a mixture comprising two parts of Buehler® Epothin 2 Epoxy resin and one part of Buehler® Epothin 2 Epoxy hardener. These thin sections were studied using Leica DM 4500P polarizing microscope attached with Leica DFC420 camera and Leica Image Analysis software (LAS- v4.6) at the Department of Earth Sciences, IIT Bombay. Eighteen sandstone thin sections were selected for modal analysis following the Gazzi-Dickinson point counting method (cf. Ingersoll et al., 1984) (Supplementary data).

Four sandstone samples, one each from Jhurio, Jhumara, Jhuran and Bhuj formations and one granite cobble from the base of the Mesozoic succession in the Cheriyabet, Khadir Island were used for heavy mineral separation. These samples were powdered using an agate ball mill until a size fraction of less than $250 \mu \mathrm{m}$ was reached. Heavy minerals were separated from the powdered sample by panning under water. The heavy mineral concentrates were then mounted in resin on glass slides. These sample mounts were polished using diamond paste $(1 \mu \mathrm{m})$.

Photomicrographs of the mounted grains were taken using an optical microscope. The mounted grains were examined under JEOL JSM-7500F scanning electron microscope using backscattered electron (BSE) and cathodoluminescence (CL) techniques at the Department of Earth and Planetary Systems Science, Hiroshima University. Monazite grains in the sample mounts were analyzed for U-Th-total Pb by EPMA (JEOL JXA-8200 Superprobe) at the Natural Science Center 
for Basic Research and Development (N-BARD), Hiroshima University. The analytical procedures followed were fundamentally the same as those of Fujii et al. (2008) following the methodology of Suzuki and Adachi (1991). A total of 216 spots was analyzed with an accelerating voltage of $15 \mathrm{kV}$, specimen current of $20 \mu \mathrm{A}$ and beam diameter of $5 \mu \mathrm{m}$ (Supplementary data). All the analytical results were monitored using data of a monazite age standard from Namaqualand, South Africa (ca. $1033 \mathrm{Ma}$, Hokada and Motoyoshi, 2006). Nearly 100 detrital zircon grains in each sample mount of the four sandstone samples and 20 detrital zircon grains in the sample mount of the granite cobble were analyzed for U-Pb isotopes using a 213nm Nd-YAG Laser (New Wave Research UP-213) coupled with Agilent 7500 ICP-MS at the Department of Earth and Planetary Systems Science, Hiroshima University. Over 450 zircon grains were analyzed at $25 \mu \mathrm{m}$ spot size (Supplementary data). The detailed analytical techniques are the same as those described by Das et al. (2017) and Saha et al. (2016). Two points of zircon standard FC1 (1099 \pm 0.6 Ma, Paces and Miller, 1993) were measured after every ten unknown sample points. The data from analysis of zircon grains were processed using PepiAge (Dunkl et al., 2008). Data with less than $10 \%$ age discordance were used for plotting the histogram and relative probability density curves. For detrital zircon grains younger than $1000 \mathrm{Ma},{ }^{206} \mathrm{~Pb} /{ }^{238} \mathrm{U}$ age was considered for plotting while ${ }^{207} \mathrm{~Pb} /{ }^{206} \mathrm{~Pb}$ age was used for older zircon grains. All graphical representations of data were made using Isoplot (version 4.15, Ludwig, 2012). In the following sections, all error values are quoted in $2 \sigma$. During each analysis session the FC1 was also analyzed as unknown for consistency standard to check the data quality. The ${ }^{206} \mathrm{~Pb} /{ }^{238} \mathrm{U}$ weighted average age values were $1101 \pm 6 \mathrm{Ma}$ for the sample of Jhurio Formation, $1098 \pm 3$ Ma for Jhumara Formation, $1096 \pm 7$ Ma for Jhuran Formation, and $1100 \pm 7$ Ma for Bhuj Formation, all are close to the reported value of $1099 \pm 0.6 \mathrm{Ma}$.

\section{Results}

\subsection{Petrography of sandstones}

Sandstones of Jhurio Formation are moderately-sorted arkoses comprising subangular quartz and feldspar grains (Fig. 3a). These sandstones contain some skeletal fragments with abundant pore-filling and grain replacive carbonate cement. Sandstones of Jhumara Formation are arkoses with sub-angular to sub-rounded grains exhibiting moderate sorting (Fig. 3b). Apart from the porefilling and grain-replacive carbonate cement, these sandstones also exhibit sparse ferruginous cement. Sandstones of Jhuran Formation are moderately-sorted arkoses containing sub-angular to sub-rounded grains (Fig. 3c). These sandstones are characterized by extensive alteration of 
feldspars mainly by carbonate and ferruginous cement. Majority of the sandstones of Bhuj Formation are arkoses with a few sub-arkoses, consisting of sub-angular to sub-rounded grains (Fig. 3d). Dolomite occurs as the predominant pore-filling cement. The monocrystalline quartz with undulose extinction dominates sandstones in all four formations. Some of the studied sandstones exhibit abraded quartz overgrowth (Fig. 3e). K-feldspar dominates over plagioclase in sandstones of all the four formations. Although rare, lithic fragments consist of mud clasts and polycrystalline quartz with distinct metamorphic fabric. Common heavy minerals in these sandstones include both transparent (zircon, rutile, tourmaline, garnet, ilmenite, monazite, apatite and epidote) and opaque varieties (Chaudhuri, 2019). Many of the zircon grains appear well rounded (Fig. 3f). Chaudhuri et al. (2018) presented a detailed study of garnet and ilmenite chemistry to conclude multiple sources for these sediments including felsic igneous and metabasic rocks.

The number of grains of quartz, feldspar and lithic (rock) fragments, counted following the Gazzi-Dickinson (cf. Ingersoll et al., 1984) method are recalculated to 100 (Supplementary data). The recalculated data are plotted in triangular QFR and QFL plots (Figs. 4a, b). Sandstones of Jhurio, Jhumara, Jhuran and Bhuj formations exhibit mean compositions of $\mathrm{Q}_{40} \mathrm{~F}_{59} \mathrm{~L}_{1}, \mathrm{Q}_{49} \mathrm{~F}_{50} \mathrm{~L}_{1}$, $\mathrm{Q}_{52} \mathrm{~F}_{47} \mathrm{~L}_{1}$ and $\mathrm{Q}_{67} \mathrm{~F}_{32} \mathrm{~L}_{1}$ respectively. Most samples occupy the field of arkose, while one sample of the Bhuj Formation plot in the field of sub-arkose (Folk, 1974) (Fig. 4a). The content of feldspar decreases from older to younger rocks, with partial overlapping of a few data points. Most of the studied sandstones occupy the transitional continental setting (Dickinson et al., 1983) (Fig. 4b). However, samples of the Jhurio Formation and a few samples of Jhumara and Jhuran formations plot within basement uplifted provenance.

\subsection{Geochronology}

\subsubsection{Basement Rock}

A granite cobble ( $\sim 6 \mathrm{~cm}$ long) in the basal conglomerate bed of Cheriyabet, yielded approximately twenty-five colorless to pale yellow zircon grains occasionally showing pink and pale brown shades. The majority of the grains are euhedral to subhedral, ranging in length between 28 and $110 \mu \mathrm{m}$. SEM-CL images show variegated internal structure including oscillatory to hourglass structures (Fig. 5a). The Wetherill concordia plot shows an age cluster around 850 Ma. (Fig. 7a). Twenty-one grains out of twenty-six measured grains yield concordant data with a single age peak in the probability density age plot (Fig. 8a). The weighted average ${ }^{206} \mathrm{~Pb} /{ }^{238} \mathrm{U}$ age of this population is $852 \pm 2.5 \mathrm{Ma}(\mathrm{n}=20, \mathrm{MSWD}=1.5)$. Th/U ratios for the near-concordant data range from 0.4 to 0.9 . 


\subsubsection{Jhurio Formation}

Monazite grains in this sample are pale brown in color, predominantly subhedral and range in size from 21 to $143 \mu \mathrm{m}$. A few grains exhibit oscillatory zoning (Fig. 6a). Analysis of 55 monazite grains yields U-Th-total $\mathrm{Pb}$ ages between $469 \pm 12 \mathrm{Ma}$ and $2548 \pm 16 \mathrm{Ma}$ with multiple peaks in the intervals of 2200-2600 Ma, 850-1050 Ma and 500-600 Ma and two major peaks at ca. $941 \mathrm{Ma}$ and $512 \mathrm{Ma}$ (Fig. 8b). Most zircon grains in this sample are colorless to pale yellow and brown, subhedral to rounded, ranging in length from 18 to $150 \mu \mathrm{m}$. SEM-CL images reveal variable CL responses with lamellar to oscillatory zoning (Fig. 5b). The Wetherill concordia plot shows multiple age clusters (Fig. 7b). Eighty-four of 109 zircon grains yield near concordant ages $(<10 \%$ discordance) ranging between $494 \pm 7 \mathrm{Ma}$ and $2836 \pm 13 \mathrm{Ma}$. The probability density plot for the near concordant data shows multiple peaks between 2500-2900 Ma, 1500-1700 Ma, 850-1000 Ma, 700-800 Ma, 500-650 Ma and 400-500 Ma, with major peaks at ca. $2541 \mathrm{Ma}, 1606 \mathrm{Ma}, 945 \mathrm{Ma}$ and $516 \mathrm{Ma}$ (Fig. 8c). Th/U data for these near-concordant grains vary widely from 0.002 to 42.697 . However, $\mathrm{Th} / \mathrm{U}$ ranges from 0.002 to 1.10 for the youngest group of zircon grains around $516 \mathrm{Ma}$. The youngest zircon population in this sample yields $492 \mathrm{Ma}(+17 /-29,95 \%$ confidence), indicating the maximum depositional age.

\subsubsection{Jhumara Formation}

Monazite grains appear pale brown, ranging in length from 14 to $100 \mu \mathrm{m}$ and exhibit varying degrees of roundness, with a few euhedral grains. Most of the grains show oscillatory zoning (Fig. 6b). Analysis of 60 monazite grains yields ages ranging from $475 \mathrm{Ma}$ to $2593 \mathrm{Ma}$, with multiple probability density peaks in the intervals of 2500-2700 Ma, 750-1000 Ma and 450-650 Ma and major peaks at ca. $936 \mathrm{Ma}$ and $533 \mathrm{Ma}$, and minor peaks at ca. $1472 \mathrm{Ma}, 1447 \mathrm{Ma}$ and 1184 Ma (Fig. 8d). Most zircon grains in this sample are colorless to pale yellow to pale brown, and sub-rounded to rounded in shape, with a few euhedral grains. These grains range in length between 18 and $207 \mu \mathrm{m}$. SEM-CL images reveal oscillatory and lamellar zoning recording variable CL responses among grains (as do those in the underlying Jhurio Formation) (Fig. 5c). The Wetherill concordia plot for this sample shows multiple age clusters (Fig. 7c). Seventy-two of 97 grains analyzed, exhibit near concordant U-Pb data ( $<10 \%$ discordance) between $470 \pm 9 \mathrm{Ma}$ and $2688 \pm$ $25 \mathrm{Ma}$. The probability density plot for the near-concordant data show multiple peaks in the age intervals of 2400-2900 Ma, 1500-2200 Ma, 750-1000 Ma, 550-650 Ma and 400-500 Ma with 
major peaks at ca. $2521 \mathrm{Ma}, 921 \mathrm{Ma}, 624 \mathrm{Ma}$ and $509 \mathrm{Ma}$ (Fig. 8e). Th/U ratios of the nearconcordant data range mostly between 0.04 and 60.8. The youngest zircon population age in this sample is calculated to be $469 \mathrm{Ma}(+16 /-21,95 \%$ confidence).

\subsubsection{Jhuran Formation}

Monazite grains in this sample range in length from 25 to $188 \mu \mathrm{m}$, exhibiting pale brown color. Internal textures of these grains exhibit oscillatory and chaotic zoning, while a few grains lack zoning (Fig. 6c). Sixty monazite grains analyzed from this sample yield ages between ca. 462 Ma and $2470 \mathrm{Ma}$ with multiple peaks in the intervals of 2300-2500 Ma, 850-1000 Ma, 600-800 Ma and 450-550 Ma, and major peaks at ca. $913 \mathrm{Ma}$ and $513 \mathrm{Ma}$, as well as a minor peak at 1554 Ma (Fig. 8f). The majority of zircon grains are sub-rounded to rounded with a few angular grains. These colorless to brown grains are 44 to $199 \mu \mathrm{m}$ long. SEM-CL images reveal oscillatory and lamellar zoning accompanied by variable CL response among grains (Fig. 5d). Apart from the age clusters exhibited by zircon grains of Jhurio and Jhumara Formations, the Wetherill concordia plot of this formation shows an additional age cluster near 2900 Ma (Fig. 7d). Eighty-seven of 100 grains yield near concordant data $(<10 \%$ discordance) ranging from $467 \pm 14$ Ma to $2902 \pm 44$ Ma. The probability density plot for the near concordant data shows multiple peaks in the age ranges of 2500-2900 Ma, 1400-2100 Ma, 800-1000 Ma, 600-750 Ma and 450-550 Ma with major peaks at ca. $2898 \mathrm{Ma}, 2509 \mathrm{Ma}, 1656 \mathrm{Ma}, 897 \mathrm{Ma}, 516 \mathrm{Ma}$ and $469 \mathrm{Ma}$ (Fig. 8g). Th/U values of nearconcordant grains vary from 0.003 to 144.30 with $500-900$ Ma grains showing the wide spread of data. The youngest zircon in this sample provides an age of $458 \mathrm{Ma}(+21 /-32,95 \%$ confidence).

\subsubsection{Bhuj Formation}

Monazite grains appear pale brown, ranging in length from 34 to $204 \mu \mathrm{m}$ and exhibit oscillatory and chaotic zoning, with a few grains lacking internal texture (Fig. 6d). Thirty-five monazite grains yield ages between ca. $451 \mathrm{Ma}$ and $2510 \mathrm{Ma}$ with multiple peaks in the intervals of 2300-2450 Ma, 850-1000 Ma, 600-800 Ma and 450-550 Ma and major peaks at ca. $968 \mathrm{Ma}$ and $518 \mathrm{Ma}$ (Fig. 8h). The minor peaks between ca. 1400 and $1500 \mathrm{Ma}$, found in the probability density plots of the Jhumara and Jhuran Formations, are absent in the Jhurio and Bhuj Formation. Zircon grains are colorless to brown, ranging in length from 43 to $272 \mu \mathrm{m}$ with subhedral to rounded in shape. SEM-CL images exhibit variable CL response in grains apart from oscillatory and lamellar zoning (Fig. 5e). Besides the age clusters exhibited by zircon grains of the Jhuran Formation, the Wetherill concordia plot for this formation shows an additional age cluster between 3200-3300 Ma 
(Fig. 7e). Seventy-eight of 107 analyzed grains yield <10\% discordant data between $502 \pm 12 \mathrm{Ma}$ and $3235 \pm 30 \mathrm{Ma}$. The probability density diagram shows multiple peaks in the age ranges of 3200-3300 Ma, 2400-2600 Ma, 1600-2200 Ma, 800-1200 Ma, 550-650 Ma and 400-500 Ma, with major peaks at ca. $3225 \mathrm{Ma}, 2524 \mathrm{Ma}, 1155 \mathrm{Ma}, 834 \mathrm{Ma}, 593 \mathrm{Ma}$ and $530 \mathrm{Ma}$ (Fig. 8i). The older zircon grains show tightly constrained $\mathrm{Th} / \mathrm{U}$ ratios ranging from 0.32 to 2.96 , but in younger ones this ratio varies between 0.09 and 164.82. The youngest zircon in this sample yields $503 \mathrm{Ma}$ $(+17 /-78,95 \%$ confidence $)$.

This research, thus highlights five major age intervals that are common in samples of all four formations viz. 400-550 Ma, 600-700 Ma, 850-1000 Ma, 1500-1600 Ma and 2400-2500 Ma (Fig. 4). The ages of detrital zircon are broadly similar to those of detrital monazite grains (Fig. 8). Some older age peaks in the interval of 2800-3300 Ma are present in samples of the Jhuran and Bhuj Formations (Figs. 8g, i). However, monazite and zircon analysis records the 400-550 Ma age interval as dominant in all four formations.

\section{Discussion}

Modal analyses indicate a gradual change in sandstone character from arkose in the older Jhurio, Jhumara and Jhuran formations to sub-arkose in the youngest Bhuj Formation (Fig. 4a). The same data indicates derivation of sediments from the uplifted basement and transitional continental settings (cf. Dickinson et al., 1983). The younger sandstones of Jhuran and Bhuj formations bear an increasing trend of cratonic signatures compared to the older counterparts (Fig. 4b). The abundance of quartz and feldspar over rock fragment indicate the predominant felsic plutonic source. Abraded quartz overgrowth and rounded zircon grains indicate long transportation and recycling of sediments (Figs. 2e, f).

The morphology of grains, CL images of zircon grains, measured ages of monazite and zircon and $\mathrm{Th} / \mathrm{U}$ ratios in zircon grains of the constituent formations suggest a mixed source of sediments with age populations in the intervals of 400-500 Ma, 500-650 Ma, 700-800 Ma, 850$1000 \mathrm{Ma}, 1500-1600 \mathrm{Ma}$ and 2400-2500 Ma and 2800-3300 Ma. Grains of each age interval show varying morphology, CL response, Th/U ratio and vice-versa (Figs. 5, 6, 7). The younger detrital zircon grains (especially 400-500 Ma, 500-650 Ma) exhibit a wider range of $\mathrm{Th} / \mathrm{U}$ ratios indicating multiple source rocks. The highest probability density in all samples indicates a predominant sediment supply from rocks of 500-650 Ma, followed by those of 400-500 Ma and 850-1000 Ma (Fig. 8). The dominance of low Th/U ratios (>0.1) exhibited by of majority of the grains across all ages indicates the magmatic source (Belousova et al., 2002), supporting the dominance of felsic 
plutonic source rocks inferred by petrography. However, a considerable fraction of the younger detritus (400-500 Ma and 500-650 Ma), especially in the Jhurio Formation with $\mathrm{Th} / \mathrm{U}<0.01$ is from metamorphic rocks (cf. Rubatto, 2002).

Rocks corresponding to >2800 Ma, 2400-2500 Ma, 1500-1600 Ma, 850-1000 Ma and 700$800 \mathrm{Ma}$ are well documented from the Indian subcontinent (Fig. 1d) (Table 1). Considering the dominant southwesterly paleocurrent, the major sources of sediments in the Kutch basin occurred in the northern and northwestern part of the Indian subcontinent. In the closest proximity to this basin, rocks older than $2500 \mathrm{Ma}$ are found in banded gneisses (Banded Gneissic Complex - BGC) of the Aravalli and the Bundelkhand cratons (Wiedenbeck and Goswami, 1994; Roy and Kröner, 1996; Mondal et al., 2002; Verma et al., 2016). Paleoproterozoic (1600-2500 Ma) rocks occur in the Aravalli and the Bhilwara Supergroups (Deb et al., 1989; Wiedenbeck et al., 1996; Kaur et al., 2011; McKenzie et al., 2013; Wang et al., 2018). Mesoproterozoic (1000-1600 Ma) rocks make up the Delhi Supergroup and the Central Indian Tectonic Zone - CITZ (Roy and Prasad, 2003, Roy and Chakraborty, 2008; Kaur et al., 2011; Purohit et al., 2012). The Erinpura Granite and the Malani Igneous Suite yield ages between 750 and 880 Ma (Crawford and Compston, 1969; Rathore et al., 1996, 1999; van Lente et al., 2009; Just et al., 2011; de Wall et al., 2018). The Nagar Parkar Igneous Suite (south-east Pakistan) ranges in age from 680-775 Ma (Khan et al., 2012, 2017b; de Wall et al., 2018; Rehman et al., 2018). The predominance of large angular clasts in the basal conglomerate unit points to their origin as scree deposits from the steeply dipping basin boundary faults. Moreover, the age of zircon grains in the granite (852 Ma) points to a distinct source, more akin to that in Malani Igneous Suite.

Granulites and per-aluminous to per-alkaline granite intrusions dating 500-650 Ma correspond to the Pan-African orogeny. The 'Pan-African orogeny', associated with the formation of Gondwana, involves a time span of a few hundred million years from Late Neoproterozoic to Early Paleozoic (Kennedy, 1964; Kröner, 1985; Black and Liegeois, 1993; Stern, 1994; Rogers et al., 1995; Roy, 2004; Rino et al., 2008). These occupy extensive areas of Gondwana including India, Sri Lanka, Africa, Arabia, Seychelles, Madagascar, Antarctica, South America and Australia (Fig. 9) (Santosh and Drury, 1988; Kriegsman, 1995; Storey et al., 1995; Torsvik et al., 1998; Rathore et al., 1999; Pande et al., 2001; Kusky et al., 2003; Yoshida et al., 2003; Roy and Purohit, 2018). Granulite belts in southern India (Santosh and Drury, 1988; Santosh et al., 1989; Choudhary et al., 1992; Yoshida et al., 1996), and some isolated outcrops in Rajasthan (Choudhary et al., 1984; Sinha-Roy et al., 1998; Rathore et al., 1999) preserve the records of this orogeny. Considering the predominant southwesterly palaeocurrent exhibited by the Mesozoic rocks in the Kutch Mesozoic 
basin, sediment detritus to the Kutch Basin could not have been derived from Madagascar and Seychelles. However, since Madagascar and Seychelles were juxtaposed with India during the time of the Pan-African orogeny, rocks equivalent to the age of the southern granulite terrain are most likely to have continued into western India before reappearing in Madagascar. Reported outcrop of Pan-African rocks nearest to the Kutch Basin is the Jalore Granite indicating a post-crystallization 500-550 Ma thermal event (Rathore et al., 1999). The End-Cretaceous Deccan Flood Basalt (DFB) cover nearly $500,000 \mathrm{~km}^{2}$ of western India and parts of central India (Fig. 1d). Therefore, the PanAfrican rocks are likely to be buried under the Deccan Flood Basalts. The high temperature of lava flows would have reset all isotope ratios of the country rock making it difficult to interpret ages of the underlying rocks. However, a few studies indicate the existence of Precambrian rocks below the Deccan basalt (Ray et al., 2008 and Upadhyay et al., 2015).

Younger peralkaline granites dating 400-500 Ma exposed along the Himalayan tectonic zone correspond to the Cambro-Ordovician tectonic events, often referred to as Bhimphedian (/or Kurgaikh) orogeny (Garzanti et al., 1986; Cawood et al., 2007; Myrow et al., 2016; Palin et al., 2018). Reported outcrops of these granites nearest to the Kutch Basin are exposed near ZanskarSpiti region and gneisses of Cambrian Tanawal Formation in the Pakistan Himalayas (Myrow et al., 2016; Palin et al., 2018). These granites formed along the Andean-type northern margin of Indian subcontinent post Gondwana break-up and are reported from the northern margin of the Indian subcontinent as isolated outcrops within Himalayan fold-thrust belt.

The wide time gap between the age of the youngest measured detrital zircon (458 Ma) and Mesozoic sedimentation indicates a) recycling of sediments from another sedimentary basin before deposition in the Kutch basin and/or b) the absence of any tectono-thermal event in the hinterland after the Ordovician. Abraded quartz overgrowth and rounded zircon grains observed in petrographic investigation reflect a combination of long distance transportation and possible recycling from one or more sedimentary rocks of a Pre-Jurassic basin. However, such a basin is unknown in northwestern India. High $\mathrm{CO}_{2}$ levels in the atmosphere resulted in high humidity and an intensified hydrological cycle during the Mesozoic (Fletcher et al., 2008; Sellwood and Valdes, 2006; Whipple and Meade, 2006). This is likely to have resulted in unusually high rates of erosion of the Pan-African and Cambro-Ordovician orogenic belts and/or recycling of Pre-Jurassic sedimentary rocks sourced from these orogenic belts, the relicts of which are preserved in northern and northwestern parts of the Indian subcontinent (Fig. 10). 


\section{Acknowledgement:}

AC is thankful to International Linkage Degree Program of the Hiroshima University. We are thankful to Yasutaka Hayasaka and Tomoyuki Shibata for their technical and laboratory support during the LA-ICPMS analysis. The fieldwork for this investigation was supported by the grant no. SR/S4/ES-709/2014 of the Department of Science and Technology, Government of India. Authors are thankful to their host institutes for infrastructure support. Authors thank Gaurav Chauhan for the palaeogeography of northwestern India. The main conclusions of this study are as follows.

(a) Petrographic characters of Mesozoic sandstones of the Kutch Basin indicate derivation of sediments from multiple source rocks, with a predominance of felsic plutonic rocks. Abraded quartz overgrowths and rounded zircon grains in these sandstones suggest long distance transportation and polycyclic nature of these sediments.

(b) Dating of detrital monazite grains and zircon grains suggests sediment derivation from multiple sources ranging in age from Archean to Ordovician. However, predominant igneous and subordinate metamorphic sources of 500-650 Ma followed by 400-500 Ma and 850-1000 Ma remained the major sediment contributors to the entire Mesozoic succession of Kutch.

c) The predominant southwesterly palaeocurrent data exhibited by Mesozoic rocks of Kutch and the detrital zircon and monazite age data points to the derivation of sediments primarily from rocks of Neoproterozoic Pan-African orogeny (500-650 Ma) and Cambro-Ordovician Bhimphedian (400$500 \mathrm{Ma}$ ) orogeny. This finding, therefore, rules out the existing view of Mesoproterozoic source of Mesozoic sediments in Kutch.

d) The paucity of outcrops of Pan-African and Bhimphedian orogeny in western and northern India relates to either burial of outcrops of the Pan-African orogeny under the Deccan basalts and those of Bhimphedian orogeny under the Himalayan thrusts or destruction of outcrops of both orogenies by unusually high rates of erosion during the Mesozoic greenhouse.

e) The absence of zircon and monazite grains younger than $458 \mathrm{Ma}$ indicates long distance sediment transport, sediment recycling as well as the absence of post Cambro-Ordovician tectonothermal events.

f) The predominant source of sediments from rocks of Pan-African and Bhimphedian orogeny indicates the existence of southerly drainage in north and northwestern India. 
helping in collection of samples. The constructive comments of the reviewer and the handling editor greatly helped to improve the quality of the manuscript.

\section{References Cited}

Ahmad, A.H.M., Bhat. G.M., 2006. Petrofacies, provenance and diagenesis of the Dhosa sandstone member (Chari formation) at Ler, Kachchh sub-basin, western India. Journal of Asian Earth Sciences 27, 857-872, https://doi.org/10.1016/j.jseaes.2005.08.005.

Ahmad, A.H.M., Noufal K.N., Masroor A.M., Tavheed, K., 2014. Petrography and geochemistry of Jumara dome sediments, Kachchh Basin: Implications for provenance, tectonic setting and weathering intensity. Chinese Journal of Geochemistry 33, 9-23, https://doi.org/10.1007/s11631-014-0656-4.

Alberti, M., Fürsich, F.T., Pandey, D.K., 2013. Deciphering condensed sequences: a case study from the Oxfordian (Upper Jurassic) Dhosa Oolite member of the Kachchh Basin, western India. Sedimentology 60, 574-598, https://doi.org/10.1111/j.1365-3091.2012.01351.x.

Arora, A., 2017. Integrated sedimentological and organic geochemical investigations of the Mesozoic Jhuran Formatiion of Kutch for palaeo-environmental interpretations. Unpublished PhD thesis. Indian Institute of Technology, Bombay, India.

Arora, A., Banerjee, S., Dutta, S., 2015. Black shale in late Jurassic Jhuran Formation of Kutch: Possible indicator of oceanic anoxic event? Journal of the Geological Society of India 85, 265-278, https://doi.org/10.1007/s12594-015-0215-6.

Arora, A., Dutta, S., Gogoi, B., Banerjee, S., 2017. The effects of igneous dike intrusion on organic geochemistry of black shale and its implications: Late Jurassic Jhuran Formation, India. International Journal of Coal Geology 178, 84-99, https://doi.org/10.1016/j.coal.2017.05.002

Bansal, U., Banerjee, S., Pande, K., Arora, A., Meena, S.S., 2017. The distinctive compositional evolution of glauconite in the Cretaceous Ukra Hill Member (Kutch basin, India) and its implications. Marine and Petroleum Geology 82, 97-117, https://doi.org/10.1016/j.marpetgeo.2017.01.017. 
Belousova, E., Griffin, W.L., O'Reilly, S.Y., Fisher, N.L., 2002. Igneous zircon: trace element composition as an indicator of source rock type. Contributions to mineralogy and petrology 143, 602-622, https://doi.org/10.1007/s00410-002-0364-7.

Biswas, S.K., 1977. Mesozoic rock-stratigraphy of Kutch, Gujarat. Quarterly Journal of the Geological Mineralogical and Metallurgical Society of India 49, 1-51.

Biswas, S.K., 1980. Mesozoic rock-stratigraphy of Kutch, Gujarat: Quarterly Journal of Geology, Mining and Metallurgy Society of India 49, 1-51.

Biswas, S.K., 1981. Basin framework, Palaeo-environment and depositional history of the Mesozoic sediments of Kutch basin, western India: Quarterly Journal of Geology, Mining and Metallurgy Society of India 53, 56-85.

Biswas, S.K., 1982. Rift basins in the western margin of India and their hydrocarbon prospects with special reference to Kutch basin: American Association of Petroleum Geologist Bulletin 66, 1497-1513.

Biswas, S.K., 1983. Cretaceous of Kutch Kathiawar region. Proceedings of the Symposium of Indian Association of Palynostratigraphers 41-65.

Biswas, S.K., 1987. Regional tectonic framework, structure and evolution of the western marginal basins of India: Tectonophysics 135, 307-327.

Biswas, S.K., 1991. Stratigraphy and sedimentary evolution of the Mesozoic basin of Kutch, western India. In: Tandon, S.K., Pant, C.C., Casshyap, S.M. (Eds.), Stratigraphy and Sedimentary Evolution of western India, Gyanodaya Prakashan, Nainital, 74-103.

Biswas, S.K., 1993. Geology of Kutch. KD Malaviya institute of petroleum exploration, Dehradun, 450.

Biswas, S.K., 1999. A review on the evolution of rift basins in India during Gondwana with special reference to western Indian basins and their hydrocarbon prospects. ProceedingsIndian National Science Academy Part A 65, 261-284.

Biswas, S.K. 2005. A review of structure and tectonics of Kutch Basin, western India, with special reference to earthquakes. Current Science 88, 1592-1600.

Biswas, S.K., Deshpande, S.V., 1968. The basement of Mesozoic sediments of Kutch, Bulletin of Geological, Mining and Metallurgical Society of India 40, 7-18. 
Black, R., Liegeois, J.P., 1993. Cratons, mobile belts, alkaline rocks and continental lithospheric mantle: the Pan-African testimony. Journal of the Geological Society 150, 8998, https://doi.org/10.1144/gsjgs.150.1.0088.

Cawood, P.A., Johnson, M.R., Nemchin, A.A., 2007. Early Palaeozoic orogenesis along the Indian margin of Gondwana: Tectonic response to Gondwana assembly. Earth and Planetary Science Letters, 255, 70-84.

Cawood, P.A., Strachan, R.A., Pisarevsky, S.A., Gladkochub, D.P. and Murphy, J.B., 2016. Linking collisional and accretionary orogens during Rodinia assembly and breakup: Implications for models of supercontinent cycles: Earth and Planetary Science Letters, 449, 118-126, https://doi.org/10.1016/j.eps1.2016.05.049.

Chaudhuri, A., 2019. Provenance, tectonic setting and palaeoweathering conditions of Middle Jurassic to Early Cretaceous sediments of Kutch. Unpublished PhD thesis. Indian Institute of Technology Bombay, India.

Chaudhuri, A, Banerjee, S., Le Pera, E., 2018. Petrography of Middle Jurasssic to Early Cretaceous sandstones in the Kutch Basin, western India: Implications on provenance and basin evolution. Journal of Palaeogeography 7, 2-14, https://doi.org/10.1186/s42501-0180002-6.

Chaudhuri, A., Banerjee, S., Chauhan, G., 2020. Compositional evolution of siliciclastic sediments recording the tectonic stability of a pericratonic rift: Mesozoic Kutch Basin, western India. Marine and Petroleum Geology 111, 476-459, https://doi.org/10.1016/j.marpetgeo.2019.08.026.

Choudhary, A.K., Gopalan, K., Sastry, C.A., 1984. Present status of the geochronology of the Precambrian rocks of Rajasthan. Tectonophysics 105, 131-140, https://doi.org/10.1016/00401951(84)90199-9.

Choudhary, A.K., Harris, N.B.W., van Calsteren, P., Hawkesworth, C.J., 1992. Pan-African charnockite formation in Kerala, south India. Geological Magazine 129, 257-264, https://doi.org/10.1017/S0016756800019208.

Collier, J.S., Sansom, V., Ishizuka, O., Taylor, R.N., Minshull, T.A., Whitmarsh, R.B., 2008. Age of Seychelles-India break-up. Earth and Planetary Science Letters 272, 264-277, https://doi.org/10.1016/j.epsl.2008.04.045. 
Crawford, A.R., Compston, W., 1969. The age of the Vindhyan system of peninsular India. Quarterly Journal of the Geological Society 125, 351-371, https://doi.org/10.1144/gsjgs.125.1.0351.

Das, K., Bose, S., Ghosh, G., 2017. The Neoarchean-Paleoproterozoic basin development and growth of the Singhbhum Craton, eastern India and its global implications: Insights from detrital zircon U-Pb data. Precambrian Research 298, 123-145, https://doi.org/10.1016/j.precamres.2017.06.008.

Deb, M., Thorpe, R.I., Cumming, G.L.,Wagner, P.A., 1989. Age, source and stratigraphic implications of $\mathrm{Pb}$ isotope data for conformable, sediment-hosted, base metal deposits in the Proterozoic Aravalli-Delhi orogenic belt, northwestern India. Precambrian Research 43, 1-22.

Desai, B.G., Biswas, S.K., 2018. Postrift deltaic sedimentation in western Kachchh Basin: Insights from ichnology and sedimentology. Palaeogeography, Palaeoclimatology, Palaeoecology 504, 104-124, https://doi.org/10.1016/j.palaeo.2018.05.013.

De Waele, B., Johnson, S.P., Pisarevsky, S.A., 2008. Palaeoproterozoic to Neoproterozoic growth and evolution of the eastern Congo Craton: its role in the Rodinia puzzle. Precambrian Research 160, 127-141, https://doi.org/10.1016/j.precamres.2007.04.020.

De Wall, H., Pandit, M.K., Donhauser, I., Schöbel, S., Wang, W., Sharma, K.K., 2018. Evolution and tectonic setting of the Malani-Nagarparkar Igneous Suite: A Neoproterozoic Silicicdominated Large Igneous Province in NW India-SE Pakistan. Journal of Asian Earth Sciences 160, 136-158, https://doi.org/10.1016/j.jseaes.2018.04.016.

Dickinson, W.R., 1988. Provenance and sediment dispersal in relation to paleotectonics and paleogeography of sedimentary basins. In New perspectives in basin analysis, Springer, New York, NY, 3-25, https://doi.org/10.1007/978-1-4612-3788-4_1.

Dickinson, W.R., Suczek, C.A., 1979. Plate tectonics and sandstone compositions. AAPG Bulletin $63,2164-2182$.

Dickinson, W.R., Beard, L.S., Brakenridge, G.R., Erjavec, J.L., Ferguson, R.C., Inman, K.F., Knepp, R.A., Lindberg, F.A., Ryberg, P.T., 1983. Provenance of North American Phanerozoic sandstones in relation to tectonic setting. Geological Society of America Bulletin 94, 222-235.

Dunkl, I., Mikes, T., Simon, K.,Von Eynatten, H., 2008. Brief introduction to the Windows program Pepita: data visualization, and reduction, outlier rejection, calculation of trace element 
Fletcher, B.J., Brentnall, S.J., Anderson, C.W., Berner, R.A., Beerling, D.J., 2008. Atmospheric carbon dioxide linked with Mesozoic and early Cenozoic climate change. Nature Geoscience 1, 43-48, https://doi.org/10.1038/ngeo.2007.29.

Folk, R.L. 1974. Petrology of sedimentary rocks. Austin: Hemphill

Fujii, M., Hayasaka, Y., Terada, K., 2008. SHRIMP zircon and EPMA monazite dating of granitic rocks from the Maizuru terrane, southwest Japan: Correlation with East Asian Paleozoic terranes and geological implications. Island Arc 17, 322-341, https://doi.org/10.1111/j.14401738.2008.00623.x.

Fürsich, F.T., Oschmann, W., Jaitly, A.K., Singh, I.B., 1991. Faunal response to transgressiveregressive cycles: example from the Jurassic of western India. Palaeogeography, Palaeoclimatology, Palaeoecology 85, 149-159, https://doi.org/10.1016/0031-0182(91)90155$\mathrm{K}$.

Fürsich, F.T., Callomon, J.H., Pandey, D.K., Jaitly, A.K., 2004. Environments and faunal patterns in the Kachchh rift basin, western India, during the Jurassic. Rivista Italiana di Paleontologia e Stratigrafia (Research In Paleontology and Stratigraphy) 110.

Fürsich, F.T., Singh, I.B., Joachimski, M., Krumm, S., Schlirf, M., Schlirf, S., 2005. Palaeoclimate reconstructions of the Middle Jurassic of Kachchh (western India): an integrated approach based on palaeoecological, oxygen isotopic, and clay mineralogical data. Palaeogeography, Palaeoclimatology, Palaeoecology 217, 289-309, https://doi.org/10.1016/j.palaeo.2004.11.026.

Garzanti, E., Casnedi, R., Jadoul, F., 1986. Sedimentary evidence of a Cambro-Ordovician orogenic event in the northwestern Himalaya. Sedimentary Geology 48, 237-265, https://doi.org/10.1016/0037-0738(86)90032-1.

Gehrels, G.E., DeCelles, P.G., Ojha, T.P., Upreti, B.N., 2006. Geologic and U-Pb geochronologic evidence for early Paleozoic tectonism in the Dadeldhura thrust sheet, far-west Nepal Himalaya. Journal of Asian Earth Sciences, 28, 385-408.

Hokada, T., Motoyoshi, Y., 2006. Electron microprobe technique for U-Th-Pb and REE chemistry of monazite, and its implications for pre-, peak-and post-metamorphic events of the Lutzow-Holm Complex and the Napier Complex, East Antarctica. 
Ingersoll, R.V., Bullard, T.F., Ford, R.L., Grimm, J.P., Pickle, J.D., Sares, S.W., 1984. The effect of grain size on detrital modes: a test of the Gazzi-Dickinson point-counting method. Journal of Sedimentary Research 54, 103-116.

Just, J., Schulz, B., de Wall, H., Jourdan, F., Pandit, M.K., 2011. Monazite CHIME/EPMA dating of Erinpura granitoid deformation: Implications for Neoproterozoic tectono-thermal evolution of NW India. Gondwana Research 19, 402-412, https://doi.org/10.1016/j.gr.2010.08.002.

Karmalkar, N.R., Duraiswami, R.A., Rao, N.C., Paul, D.K., 2009. Mantle-derived maficultramafic xenoliths and the nature of Indian sub-continental lithosphere. Journal of the Geological Society of India 73, 657-679, https://doi.org/10.1007/s12594-009-0051-7.

Karmalkar, N.R., Duraiswami, R.A., Jonnalagadda, M.K., Griffin, W.L., 2014. Mid-Cretaceous lamproite from the Kutch region, Gujarat, India. Genesis and tectonic implications: Gondwana Research 26, 942-956, https://doi.org/10.1016/j.gr.2013.09.012.

Kaur, P., Zeh, A., Chaudhri, N., Gerdes, A., Okrusch, M., 2011. Archaean to Palaeoproterozoic crustal evolution of the Aravalli mountain range, NW India, and its hinterland: the $\mathrm{U}-\mathrm{Pb}$ and $\mathrm{Hf}$ isotope record of detrital zircon. Precambrian Research 187, 155-164, https://doi.org/10.1016/j.precamres.2011.03.005.

Kennedy, W.Q., 1964. The structural differentiation of Africa in the Pan-Africa ( \pm 500 my) tectonic episode. University of Leeds, Research Institute of African Geology, Annual Report, 48-49.

Khan, T., Murata, M., Rehman, H.U., Zafar, M., Ozawa, H., 2012. Nagarparker granites showing Rodinia remnants in the southeastern part of Pakistan. Journal of Asian Earth Sciences 59, 3951, https://doi.org/10.1016/j.jseaes.2012.05.028.

Khan, S., Quasim, M.A., Ahmad, A.H.M., Alam, M.M., 2017a. Petrofacies and Tectono Provenance of the Sandstones of Jara Dome, Kachchh, Gujarat. Jour. Indian Assoc. Sediment 34, 17-28.

Khan, T., Murata, M., Jan, M.Q., Rehman, H.U., Zafar, M., Ozawa, H., Qadir, A., Mehmood, S., 2017b. Felsic dykes in the Neoproterozoic Nagar Parkar Igneous Complex, SE Sindh, Pakistan: geochemistry and tectonic settings. Arabian Journal of Geosciences 10, 308, https://doi.org/10.1007/s12517-017-3077-y. 
Kreuser, T., 1995. Rift to drift evolution in Permian-Jurassic basins of East Africa. Geological Society, $\quad$ London, $\quad$ Special Publications $\quad 80, \quad 297-315$, https://doi.org/10.1144/GSL.SP.1995.080.01.14.

Kriegsman, L.M., 1995. The Pan-African event in East Antarctica: a view from Sri Lanka and the Mozambique belt. Precambrian Research 75, 263-277, https://doi.org/10.1016/03019268(95)80010-F.

Krishna, J., 2017. The Indian Mesozoic chronicle. Springer, Singapore.

Kröner, A., 1985. Ophiolites and the evolution of tectonic boundaries in the late Proterozoic Arabian-Nubian shield of northeast Africa and Arabia. Precambrian Research 27, 277-300, https://doi.org/10.1016/0301-9268(85)90016-6.

Kshirsagar, P.V., Sheth, H.C., Shaikh, B., 2011. Mafic alkalic magmatism in central Kachchh, India: a monogenetic volcanic field in the northwestern Deccan Traps. Bulletin of Volcanology 73, 595-612, https://doi.org/10.1007/s00445-010-0429-9.

Kusky, T.M., Abdel Salam, M.G., Stern, R.J., Tucker, R.D., 2003. Evolution of the East African and related orogens, and the assembly of Gondwana. Precambrian Research 123, 81-85. https://doi.org/10.1016/S0301-9268(03)00062-7.

Ludwig, K.R., 2012. User's manual for Isoplot 3.75. A geochronological toolkit for Microsoft Excel. Berkeley Geochronology Center Special Publication.

Mandal, A., Koner, A., Sarkar, S., Tawfik, H.A., Chakraborty, N., Bhakta, S., Bose, P.K., 2016. Physico-chemical tuning of palaeogeographic shifts: Bhuj formation, Kutch, India. Marine and Petroleum Geology 78, 474-492, https://doi.org/10.1016/j.marpetgeo.2016.10.003.

McKenzie, N.R., Hughes, N.C., Myrow, P.M., Banerjee, D.M., Deb, M., Planavsky, N.J., 2013. New age constraints for the Proterozoic Aravalli-Delhi successions of India and their $\begin{array}{llll}\text { implications. } & \text { Precambrian } & \text { Research }\end{array}$ https://doi.org/10.1016/j.precamres.2013.10.006.

Mondal, M.E.A., Goswami, J.N., Deomurari, M.P., Sharma, K.K., 2002. Ion microprobe $207 \mathrm{~Pb} / 206 \mathrm{~Pb}$ ages of zircons from the Bundelkhand massif, northern India: implications for crustal evolution of the Bundelkhand-Aravalli protocontinent. Precambrian Research 117, 85-100, https://doi.org/10.1016/S0301-9268(02)00078-5. 
Myrow, P.M., Hughes, N.C., McKenzie, N.R., Pelgay, P., Thomson, T.J., Haddad, E.E., Fanning, C.M., 2016. Cambrian-Ordovician orogenesis in Himalayan equatorial Gondwana. Bulletin, 128, 1679-1695.

Nikishin, A.M., Ziegler, P.A., Stephenson, R.A., Cloetingh, S.A.P.L., Furne, A.V., Fokin, P.A., Ershov, A.V., Bolotov, S.N., Korotaev, M.V., Alekseev, A.S., Gorbachev, V.I., 1996. Late Precambrian to Triassic history of the East European Craton: dynamics of sedimentary basin evolution. Tectonophysics 268, 23-63, https://doi.org/10.1016/S0040-1951(96)00228-4.

Paces, J.B., Miller Jr, J.D., 1993. Precise U- Pb ages of Duluth complex and related mafic intrusions, northeastern Minnesota: Geochronological insights to physical, petrogenetic, paleomagnetic, and tectonomagmatic processes associated with the $1.1 \mathrm{Ga}$ midcontinent rift system. Journal of Geophysical Research. Solid Earth, 98, 13997-14013.

Palin, R.M., Treloar, P.J., Searle, M.P., Wald, T., White, R.W., Mertz-Kraus, R., 2018. U-Pb monazite ages from the Pakistan Himalaya record pre-Himalayan Ordovician orogeny and Permian continental breakup. Bulletin, 130, 2047-2061.

Pande, K., Sheth, H.C., Bhutani, R., 2001. 40Ar-39Ar age of the St. Mary's Islands volcanics, southern India: record of India-Madagascar break-up on the Indian subcontinent. Earth and Planetary Science Letters 193, 39-46, https://doi.org/10.1016/S0012-821X(01)00495-2.

Purohit, R., Papineau, D., Kröner, A., Sharma, K.K., Roy, A.B., 2012. Carbon isotope geochemistry and geochronological constraints of the Neoproterozoic Sirohi Group from northwest India. Precambrian Research 80-90, https://doi.org/10.1016/j.precamres.2012.07.012

Ramakrishnan, M., R. Vaidyanadhan. 2008. Geology of India. Vol. 1, 261-333. Bangalore. Geological Society of India.

Rathore, S.S., Venkatesan, T.R., Srivastava, R.K., 1996. Rb- Sr and Ar- Ar systematics of Malani volcanic rocks of southwest Rajasthan: Evidence for a younger post-crystallization thermal event. Proceedings of the Indian Academy of Sciences-Earth and Planetary Sciences 105, 131-141, https://doi.org/10.1007/BF02876009.

Rathore, S.S., Venkatesh, T.R., Srivastava, R.K., 1999. Rb-Sr isotope dating of Neoproteroozic (Malani Group) magmatism from southwest Rajasthan, India: evidence of younger Pan-African 
thermal event by 40Ar-39Ar studies. Gondwana Research 2, 271-281, https://doi.org/10.1016/S1342-937X(05)70151-9.

Ray, A., Patil, S.K., Paul, D.K., Biswas, S.K., Das, B., Pant, N.C., 2006. Petrology, geochemistry and magnetic properties of Sadara sill: Evidence of rift related magmatism from Kutch basin, northwest India. Journal of Asian Earth Sciences 27, 907-921, https://doi.org/10.1016/j.jseaes.2005.09.006.

Ray, R., Shukla, A.D., Sheth, H.C., Ray, J.S., Duraiswami, R.A., Vanderkluysen, L., Rautela, C.S., Mallik, J., 2008. Highly heterogeneous Precambrian basement under the central Deccan Traps, India: direct evidence from xenoliths in dykes. Gondwana Research 13, 375385.

Rehman, H.U., Khan, T., Jan, M.Q., Lee, H.Y., Chung, S.L., Murata, M., 2018. Timing and span of the continental crustal growth in SE Pakistan: Evidence from LA-ICP-MS U-Pb zircon ages from granites of the Nagar Parkar Igneous Complex. Gondwana Research 61, 172-186, https://doi.org/10.1016/j.gr.2018.04.018.

Rino, S., Kon, Y., Sato, W., Maruyama, S., Santosh, M., Zhao, D., 2008. The Grenvillian and Pan-African orogens: world's largest orogenies through geologic time, and their implications on the origin of superplume. Gondwana Research 14, 51-72, https://doi.org/10.1016/j.gr.2008.01.001.

Rogers, J.J., Unrug, R., Sultan, M., 1995. Tectonic assembly of Gondwana. Journal of Geodynamics 19, 1-34, https://doi.org/10.1016/0264-3707(94)00007-7.

Roy, A.B., 2004. The Phanerozoic reconstitution of Indian Shield as the aftermath of break-up of the Gondwanaland. Gondwana research 7, 387-406, https://doi.org/10.1016/S1342937X(05)70792-9.

Roy, A., Chakraborty, K., 2008. Precambrian mafic-ultramafic magmatism in Central Indian suture zone. Journal of Geological Society of India 72, 123-140.

Roy, A.B., Kröner, A., 1996. Single zircon evaporation ages constraining the growth of the Archaean Aravalli craton, northwestern Indian shield. Geological Magazine 133, 333-342, https://doi.org/10.1017/S0016756800009067.

Roy, A.B., Purohit, R., 2018. Indian Shield. Precambrian Evolution and Phanerozoic Reconstitution. Elsevier. 
Roy, A., Prasad, M.H., 2003. Tectonothermal events in Central Indian Tectonic Zone (CITZ) and its implications in Rodinian crustal assembly. Journal of Asian Earth Sciences 22, 115-129, https://doi.org/10.1016/S1367-9120(02)00180-3.

Rubatto, D., 2002. Zircon trace element geochemistry: partitioning with garnet and the link between $\mathrm{U}-\mathrm{Pb}$ ages and metamorphism. Chemical geology 184, 123-138, https://doi.org/10.1016/S0009-2541(01)00355-2.

Saha, S., Das, K., Hidaka, H., Kimura, K., Chakraborty, P.P., Hayasaka, Y., 2016. Detrital zircon geochronology (U-Pb SHRIMP and LA-ICPMS) from the Ampani Basin, Central India: Implication for provenance and Mesoproterozoic tectonics at East Indian cratonic margin. Precambrian Research 281, 363-383, https://doi.org/10.1016/j.precamres.2016.06.011.

Santosh, M., Drury, S.A., 1988. Alkali granites with Pan-African affinities from Kerala, S. India. Journal of Geology 96, 616-626, https://doi.org/10.1086/629257.

Santosh, M., Iyer, S.S., Vasconcellos, M.B.A., Enzweiler, J., 1989. Late Precambrian alkaline plutons in southwest India: geochronologic and rare-earth element constraints on Pan-African magmatism. Lithos 24, 65-79, https://doi.org/10.1016/0024-4937(89)90016-9.

Scotese, C. R., 1997. Paleogeographic Atlas, PALEOMAP Progress Report 90-0497, Department of Geology, University of Texas at Arlington, Arlington, Texas, 37.

Sellwood, B.W., Valdes, P.J., 2006. Mesozoic climates: General circulation models and the rock record. Sedimentary Geology 190, 269-287, https://doi.org/10.1016/j.sedgeo.2006.05.013.

Sinha-Roy, S., Malhotra, G., Mohanty, M., 1998. Geology of Rajasthan: Geological Society of India, Bangalore. 278.

Stephenson, R.A., Yegorova, T., Brunet, M.F., Stovba, S., Wilson, M., Starostenko, V., Saintot, A., Kusznir, N., 2006. Late Palaeozoic intra-and pericratonic basins on the East European Craton and its margins. Geological Society, London, Memoirs 32, 463-479, https://doi.org/10.1144/GSL.MEM.2006.032.01.29.

Stern, R.J., 1994. Arc assembly and continental collision in the Neoproterozoic East African Orogen: implications for the consolidation of Gondwanaland. Annual Review of Earth and Planetary Sciences 22, 319-351. 
Storey, M., Mahoney, J.J., Saunders, A.D., Duncan, R.A., Kelley, S.P., Coffin, M.F., 1995. Timing of hot spot-related volcanism and the breakup of Madagascar and India, Science 267, 852855.

Suzuki K., Adachi M. 1991. Precambrian provenance and Silurian metamorphism of the Tubonosawa paragneiss in the South Kitakami terrane, Northeast Japan, revealed by the chemical $\mathrm{U}-\mathrm{Th}$-total $\mathrm{Pb}$ isochron ages of monazite, zircon and xenotime. Geochemical Journal 25, 357-76, https://doi.org/10.2343/geochemj.25.357.

Torsvik, T.H., Tucker, R.D., Ashwald, L.D., Eidea, E.A., Rakotosolofod, N.A., de Wite, M.J., 1998. Late Cretaceous magmatism in Madagascar: palaeomagnetic evidence for a stationary Marion hotspot. Earth Planetary Science Letters 164, 221-232, https://doi.org/10.1016/S0012821X(98)00206-4.

Upadhyay, D., Kooijman, E., Singh, A.K., Mezger, K., Berndt, J., 2015. The basement of the Deccan Traps and its Madagascar connection: constraints from xenoliths. Journal of Geology 123, 295-307, https://doi.org/10.1086/682009.

Van Lente, B., Ashwal, L.D., Pandit, M.K., Bowring, S.A., Torsvik, T.H., 2009. Neoproterozoic hydrothermally altered basaltic rocks from Rajasthan, northwest India: implications for late Precambrian tectonic evolution of the Aravalli Craton. Precambrian Research 170, 202-222, https://doi.org/10.1016/j.precamres.2009.01.007.

Verma, S.K., Verma, S.P., Oliveira, E.P., Singh, V.K., Moreno, J.A., 2016. LA-SF-ICP-MS zircon $\mathrm{U}-\mathrm{Pb}$ geochronology of granitic rocks from the central Bundelkhand greenstone complex, Bundelkhand craton, India. Journal of Asian Earth Sciences 118, 125-137, https://doi.org/10.1016/j.jseaes.2015.12.021.

Wang, J., Li, Z.X., 2003. History of Neoproterozoic rift basins in South China: implications for Rodinia break-up. Precambrian Research 122, 141-158, https://doi.org/10.1016/S03019268(02)00209-7.

Wang, W., Cawood, P.A., Pandit, M.K., Xia, X.P., Zhao, J.H., 2018. Coupled Precambrian crustal evolution and supercontinent cycles: Insights from in-situ U-Pb, O-and Hf-isotopes in detrital zircon, NW India. American Journal of Science 318, 989-1017, https://doi: 10.2475/10.2018.01. 
Wiedenbeck, M., Goswami, J.N., 1994. High precision 207Pb206Pb zircon geochronology using a small ion microprobe. Geochimica et Cosmochimica Acta 58, 2135-2141, https://doi.org/10.1016/0016-7037(94)90291-7.

Wiedenbeck, M., Goswami, J.N., Roy, A.B., 1996. Stabilization of the Aravalli Craton of northwestern India at $2.5 \mathrm{Ga}$ : an ion microprobe zircon study. Chemical Geology 129, 325-340, https://doi.org/10.1016/0009-2541(95)00182-4.

Whipple, K.X., Meade, B.J., 2006. Orogen response to changes in climatic and tectonic forcing. Earth and Planetary Science Letters 243, 218-228, https://doi.org/10.1016/j.epsl.2005.12.022.

Yoshida, M., Bindu, R.S., Kagami, H., Rajesham, T., Santosh, M., Shirahata, H., 1996. Geochronologic constraints of granulite terranes of South India and their implications for the Precambrian assembly of Gondwana. Journal of Southeast Asian Earth Sciences 14, 137-47, https://doi.org/10.1016/S0743-9547(96)00053-0.

Yoshida, M., Jacobs, J., Santosh, M., Rajesh, H.M., 2003. Role of Pan-African events in the Circum-East Antarctic orogen of East Gondwana: a critical overview. Geological Society, London, Special Publications 206, 57-75, https://doi.org/10.1144/GSL.SP.2003.206.01.05.

\section{Figure Captions}

Fig. 1. (a) Stratigraphic divisions of the Mesozoic succession of the Kutch Mainland (Biswas, 1977, 1999; Krishna, 2017); (b) composite log of study area (adapted from Biswas, 2005; Fürsich et al. 2005; Mandal et al. 2016) showing sample locations and available palaeocurrent data (number of data for $\mathrm{i}$ and ii are 13 and 141 respectively from Mandal et al., 2016; number of data for iii and iv are 62 and 114 respectively from Arora, 2017); (c) map of the Kutch Basin with tectonic elements, black arrow indicates the inferred palaeoslope, green dots indicate sample locations (adapted from Biswas, 1991); (d) map of north and north-western India showing outcrops of possible source areas (adapted from Biswas, 1991; Biswas, 2005; Gehrels et al., 2006; Myrow et al., 2006; Ramakrishnan and Vaidyanathan, 2008; Palin et al., 2018). PU = Patcham Uplift; KU = Khadir Uplift; BU = Bela Uplift; CU = Chorar Uplift; WU = Wagad Uplift; KMU = Kutch Mainland Uplift; NPU = Nagar Parkar Uplift; NPF = Nagar Parkar Fault; IBF = Island Belt Fault; SWF = South Wagad Fault; $\mathrm{KMF}=$ Kutch Mainland Fault; KHF = Katrol Hill Fault; NKF = North Kathiawar Fault; BHG = Banni Half Graben; GoK-HG = Gulf of Kutch Half Graben

Fig. 2. Field photographs showing (a) the bedding surface of the basal Cheriyabet conglomerate at Khadir Island containing angular to sub-rounded clasts; (b) tool marks (black arrows) on the bottom 
surface of a sandstone bed in the Jhurio Formation; (c) cross-stratified sandstone (foreset orientation marked by black dashes) in the Jhumara Formation; (d) vertical section showing sheet-like sandstones with gutter casts (red arrows) belonging to the Jhuran Formation, cross-stratified sandstones (foreset orientation marked by black dashes at the upper part of the Bhuj Formation $($ coin diameter $=2 \mathrm{~cm}$, pen length $=14 \mathrm{~cm})$

Fig. 3. Photomicrographs of (a) sandstones showing quartz (yellow arrow) and replaced feldspars (red arrow) in Jhurio Formation; (b) fresh plagioclase feldspar (red arrow), carbonate cement (green arrow) and zircons (yellow arrows) in Jhumara Formation; (c) quartz (yellow arrow), fresh feldspars (red arrows) and extensive carbonate cement filling pore spaces (green arrow) in Jhuran Formation; (d) fresh feldspars (red arrows) and pore-filling dolomitic cement (yellow arrow) in Bhuj Formation; (e) abraded quartz overgrowth in Jhuran Formation; (f) rounded zircon in Jhuran Formation

Fig. 4. (a) QFR plot (field boundaries after Folk, 1974) and (b) QFL plot (field boundaries adapted from Dickinson et al., 1983) for sandstones of Jhurio, Jhumara, Jhuran and Bhuj formations (Q total quartzose grains, including monocrystalline $(\mathrm{Qm})$ and polycrystalline $(\mathrm{Qp})$ varieties without metamorphic fabric, $\mathrm{F}$ - total feldspar grains, $\mathrm{R} / \mathrm{L}$ - total unstable rock/lithic fragments)

Fig. 5. Representative collaged SEM-CL images of zircon grains with near concordant data of spot ages in (a) basal conglomerate, (b) Jhurio, (c) Jhumara, (d) Jhuran and (e) Bhuj formations (grey circles - location of laser ablation spots - not to scale)

Fig. 6. Representative collaged SEM-BSE images of monazite grains with spot ages in (a) Jhurio, (b) Jhumara, (c) Jhuran and (d) Bhuj formations (white and grey circles - location of electron microprobe spots - not to scale)

Fig. 7. Wetherill Concordia diagram and plots of $\mathrm{Th} / \mathrm{U}$ versus ${ }^{207} \mathrm{~Pb} /{ }^{235} \mathrm{U}$ for samples of (a) basal conglomerate, (b) Jhurio, (c) Jhumara, (d) Jhuran and (e) Bhuj formation. The data point error ellipses are $2 \sigma$

Fig.8. Probability density patterns of measured zircon and monazite grains from the (a) basal conglomerate, (b, c) Jhuro, (d, e) Jhumara, (f, g) Jhuran and (h, i) Bhuj formation

Fig. 9. Plate tectonic reconstruction of the position of fragments of Gondwana supercontinent in the Late Jurassic highlighting the extent of Late Neoproteroszoic-Early Cambrian Pan-African Orogeny (adapted form Kusky et al., 2003 and Scotese, 1997)

Fig. 10. Schematic diagram of Early Cretaceous palaeogeography of the Kutch Basin and its provenance areas (adapted from Biswas, 1991)

\section{Table captions}

Table 1. A compilation of recorded magmatic events in north and north-east of study area 


\section{Supplementary data}

1. Results of petrographic modal analysis of constituent Mesozoic formations (key at the end)

2. Data for monazite geochronology (EPMA)

3. Data for zircon geochronology (LA-ICPMS) 

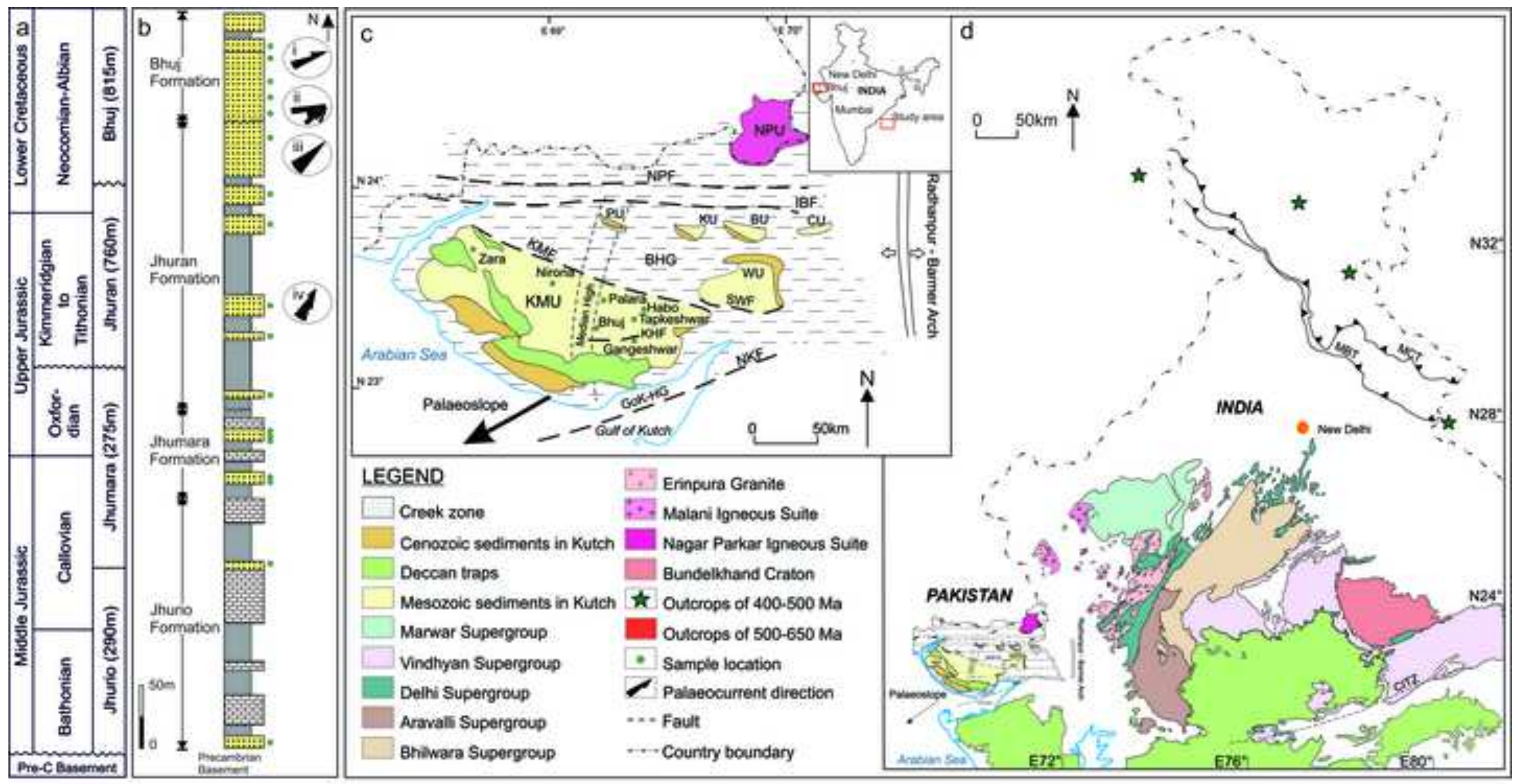

Fig. 1 
Figure
Click here to download high resolution image

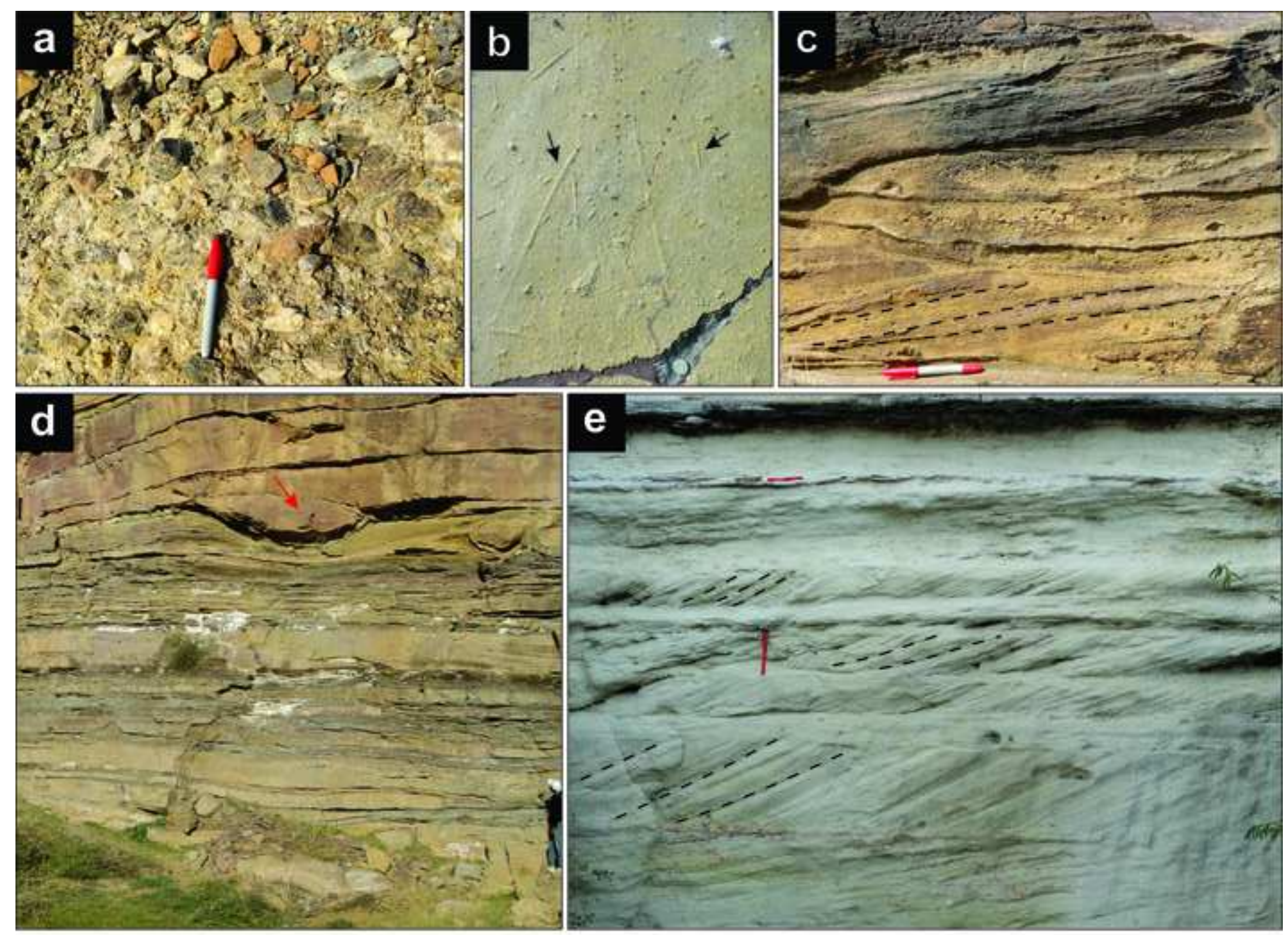

Fig. 2 

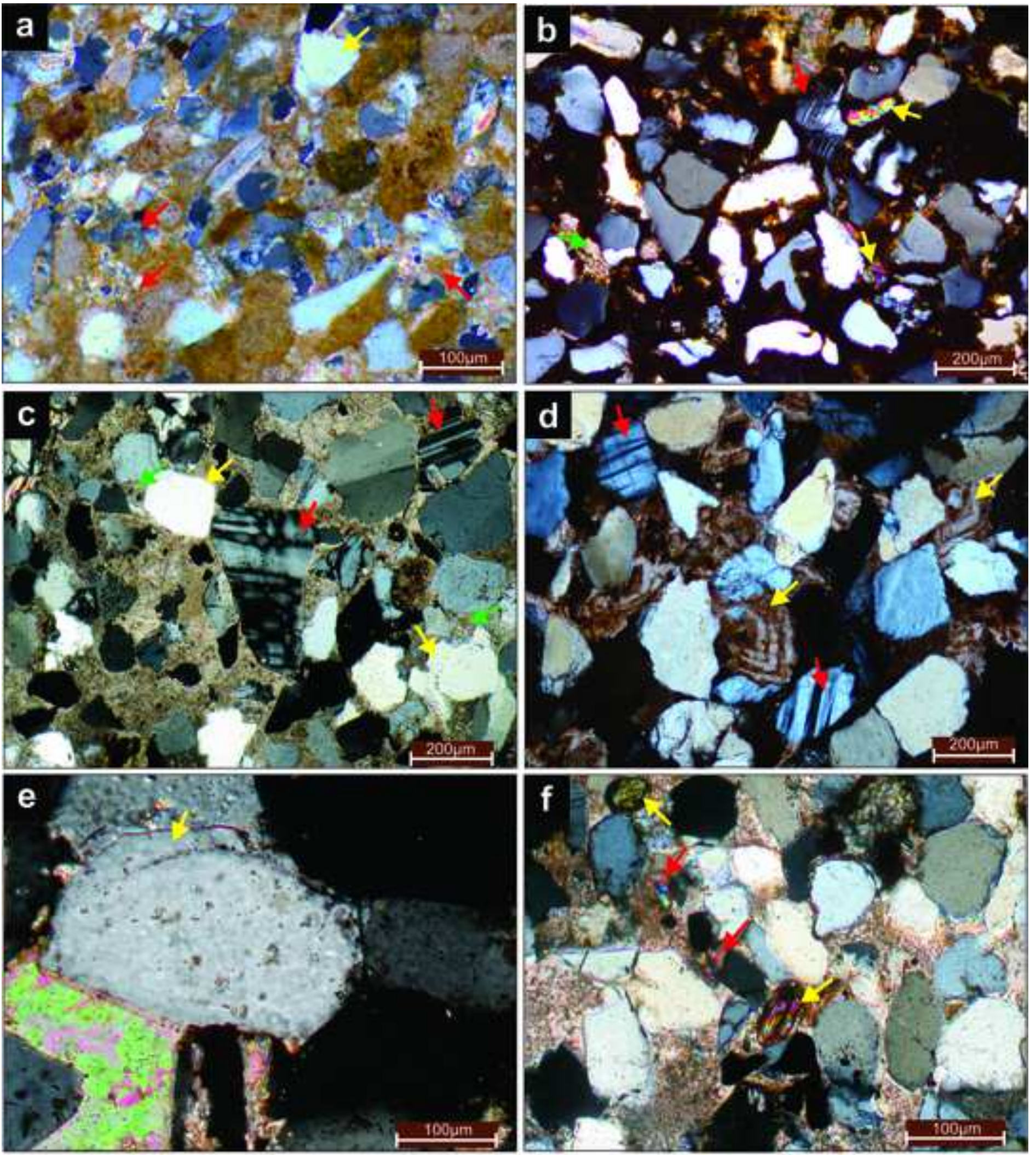

Fig. 3 


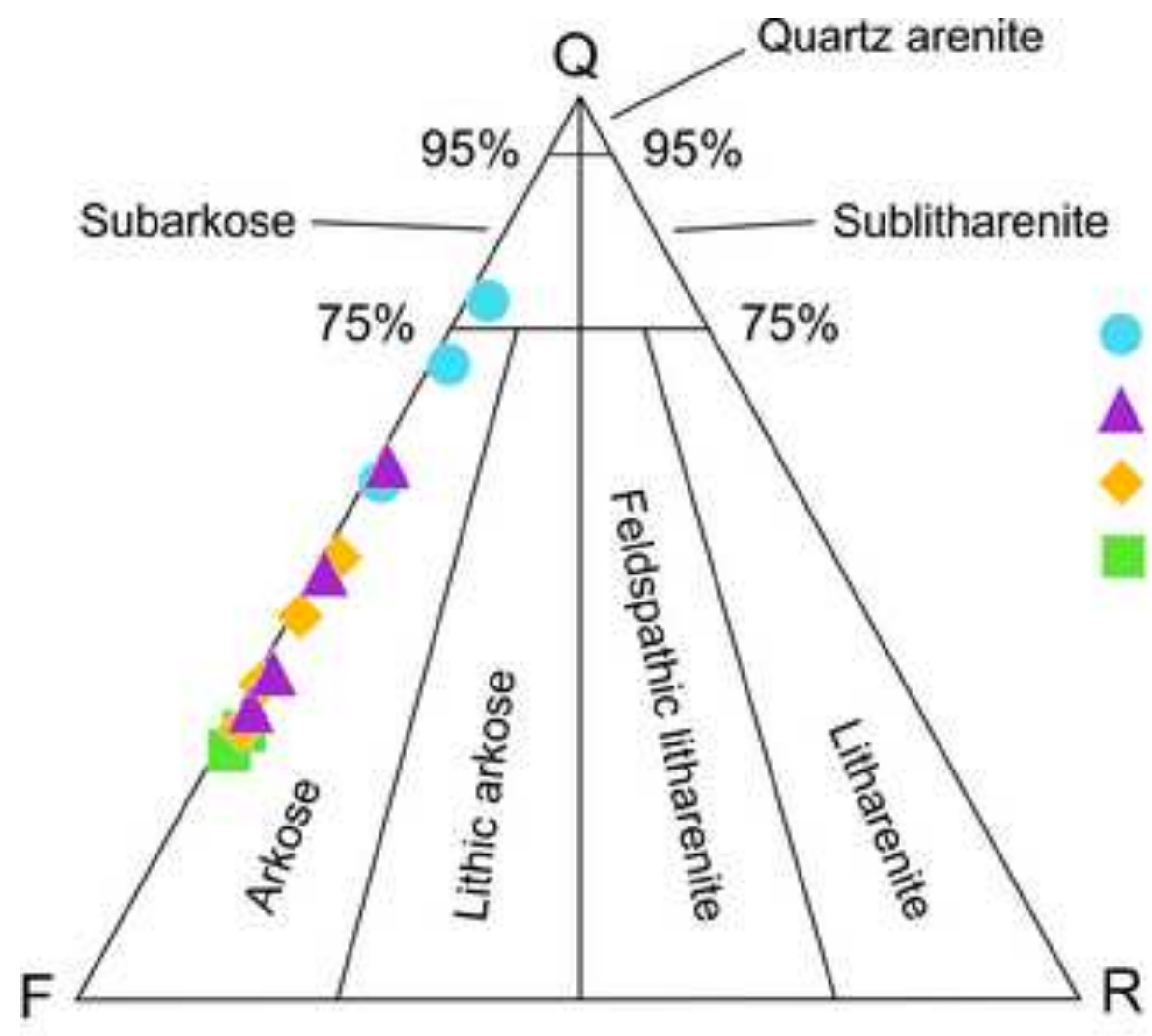

a

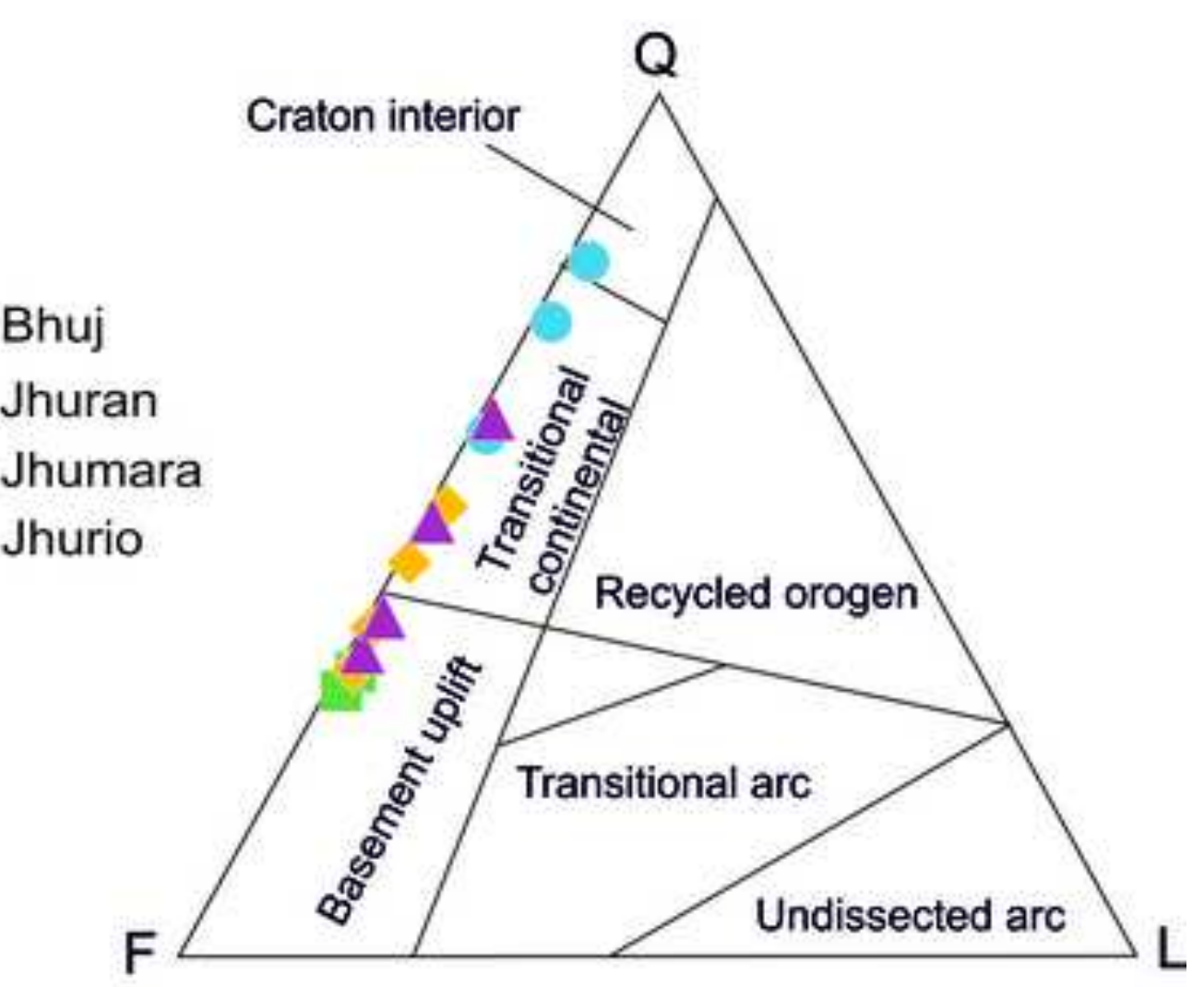

b

Fig. 4 


\section{Figure}

Click here to download high resolution image
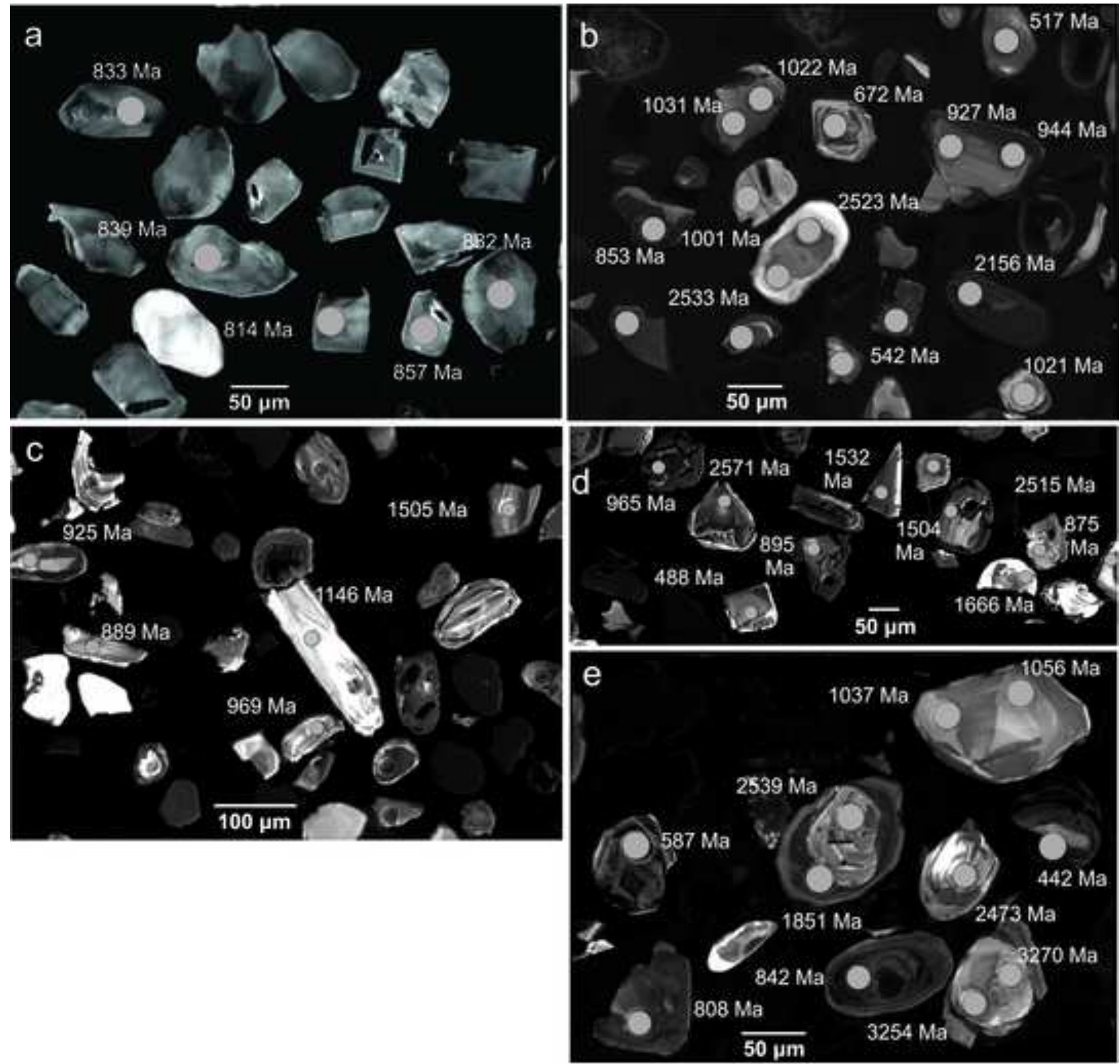

Fig. 5 


\section{Figure}

Click here to download high resolution image
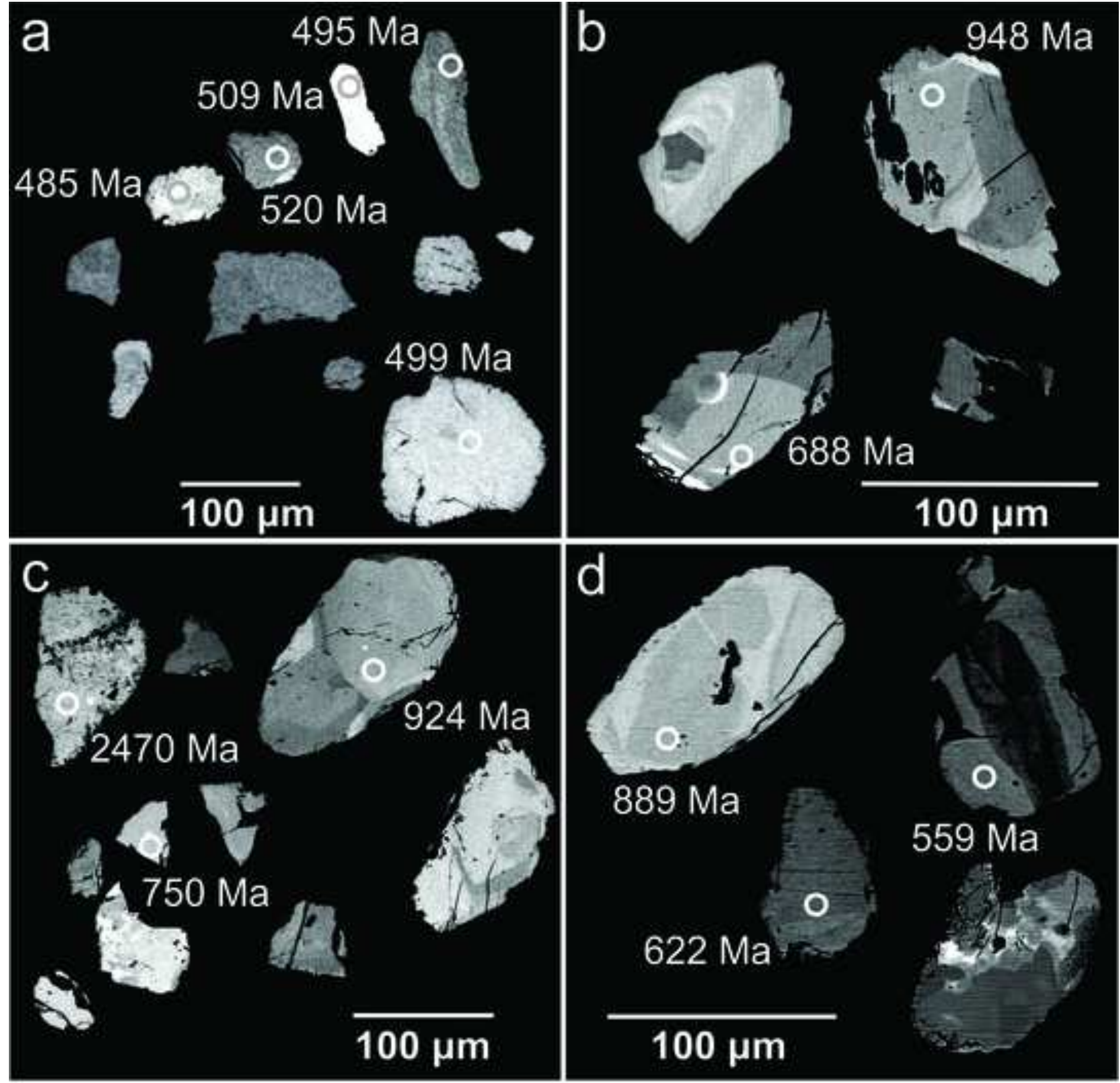

889 Mla

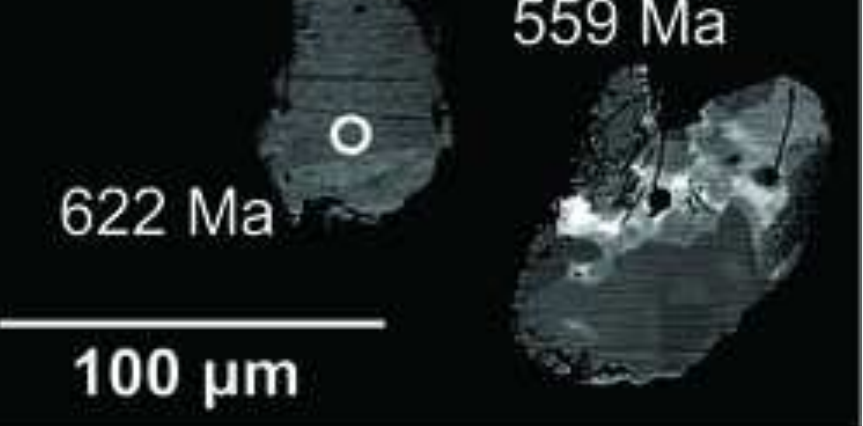

Fig. 6 


\section{Figure}

Click here to download high resolution image
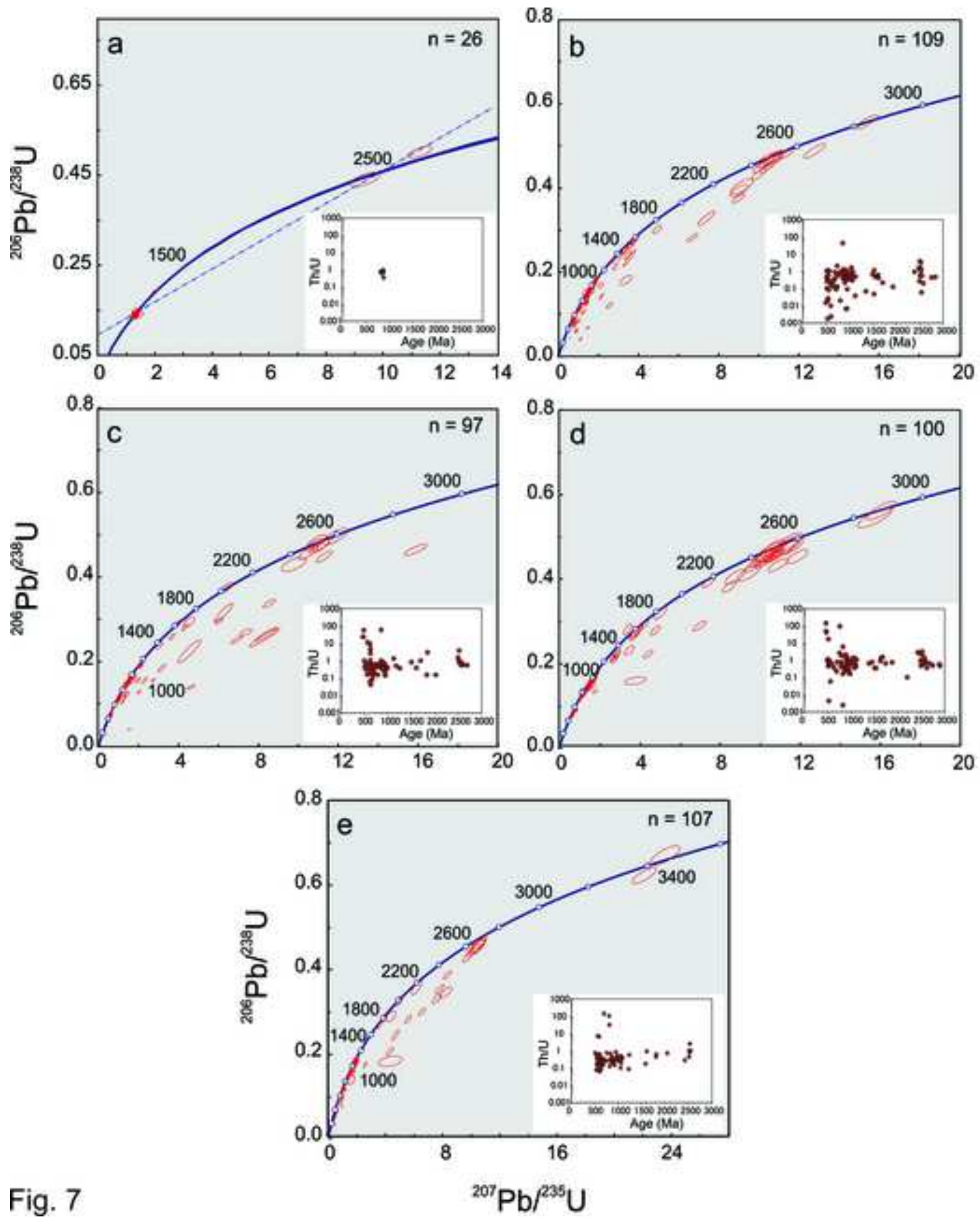

Fig. 7 


\section{Figure}

Click here to download high resolution image
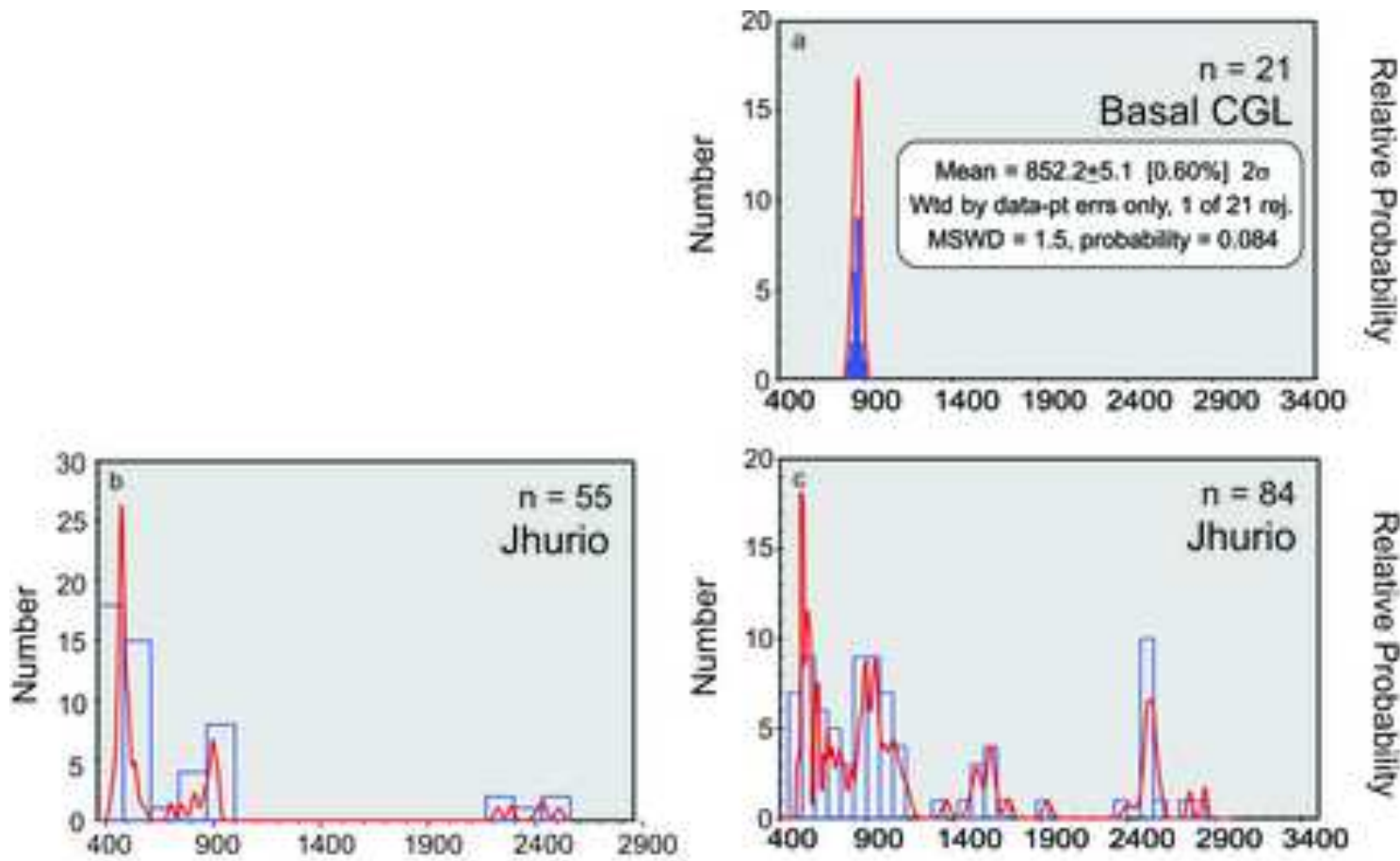

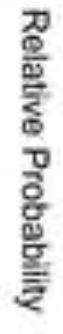
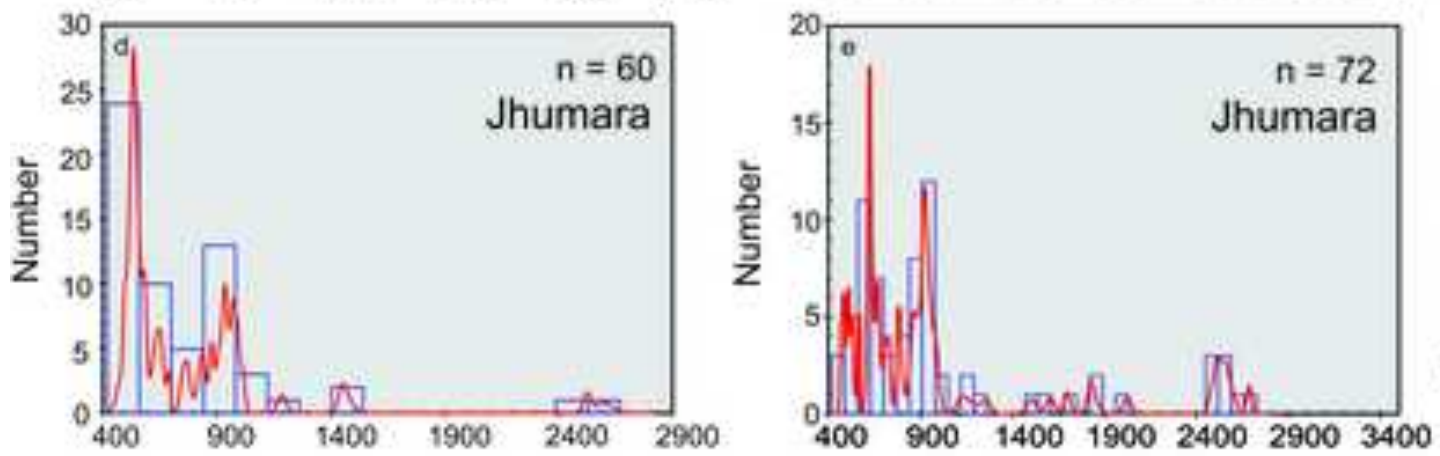

을
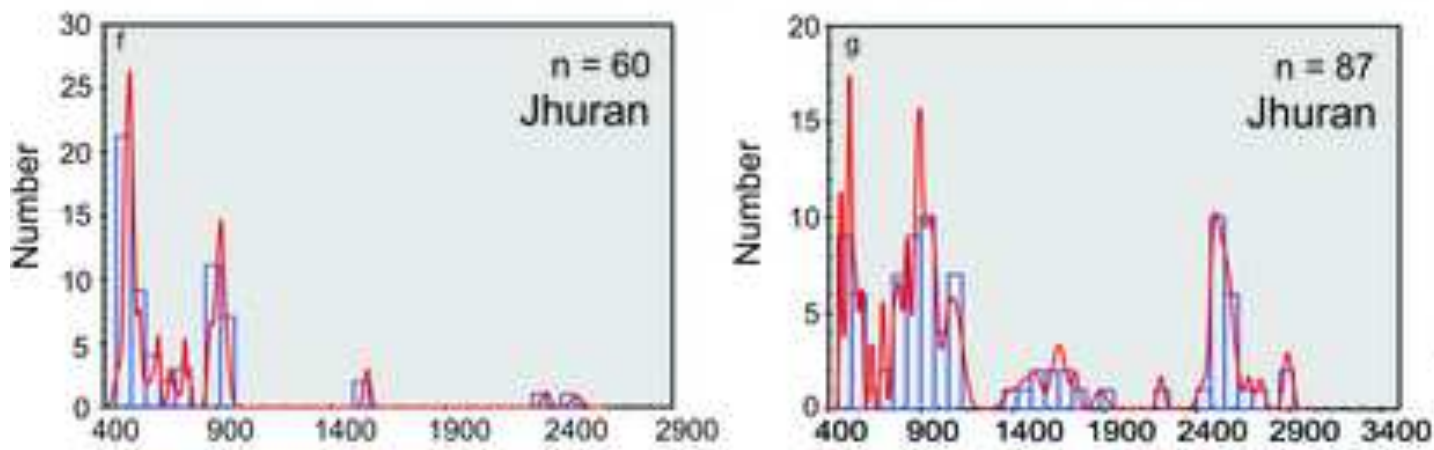

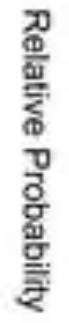
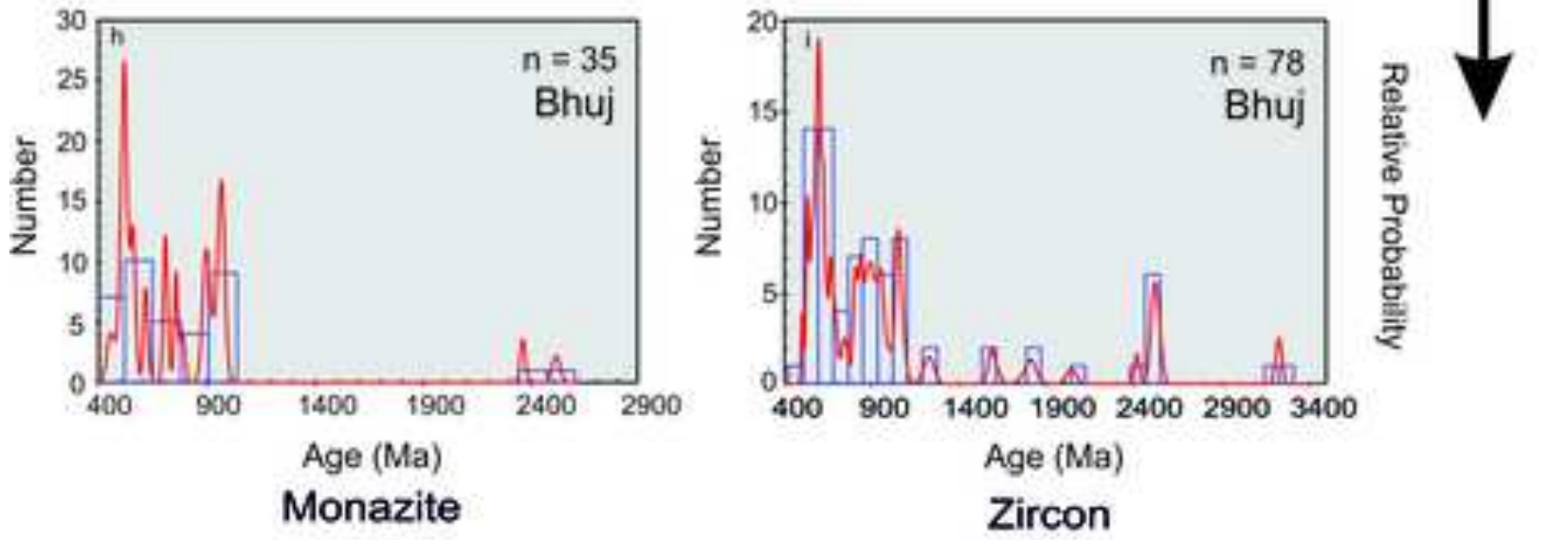

Fig. 8 


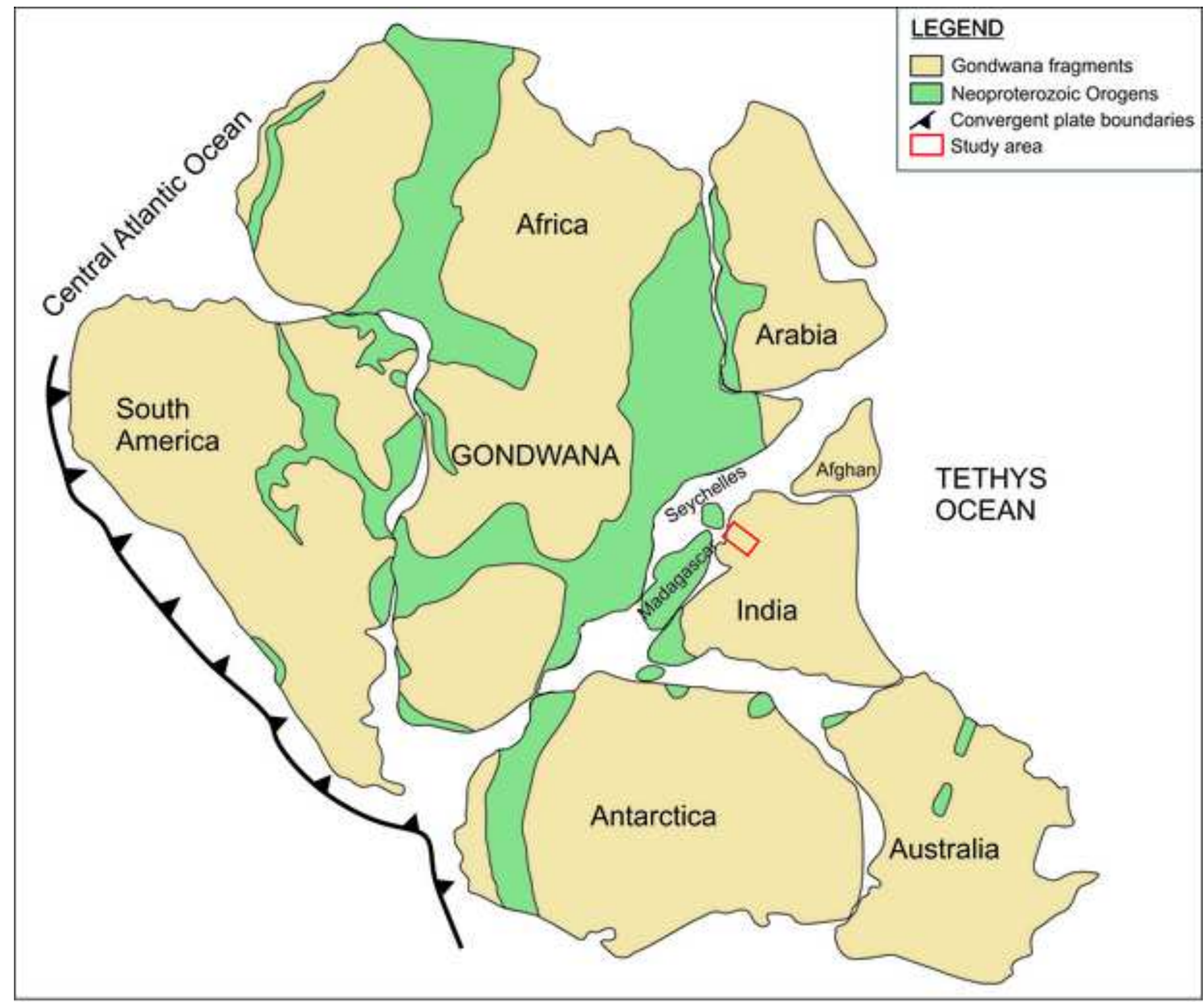

Fig. 9 


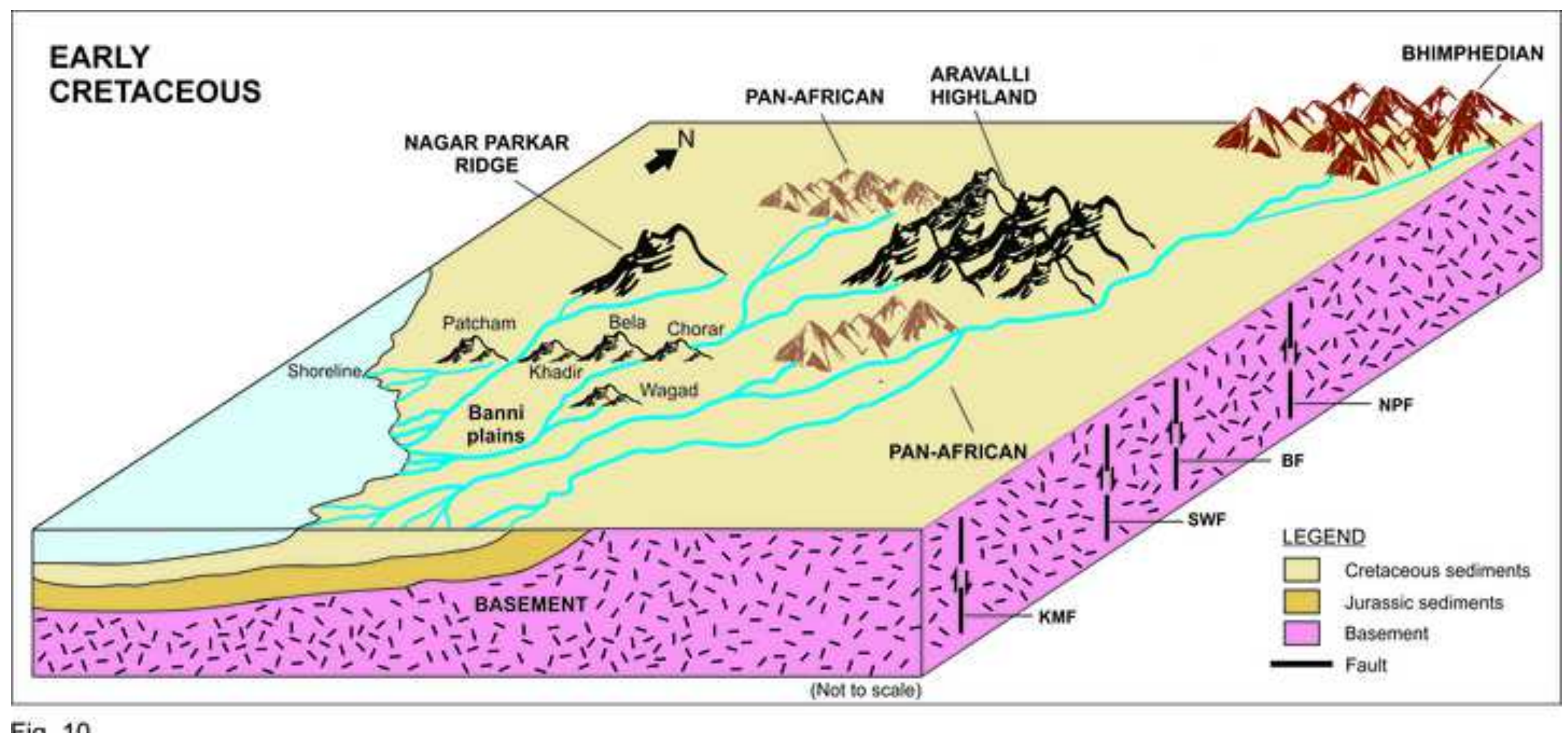

Fig. 10

(1) 


\section{Table 1}

A compilation of recorded magmatic events in north and north-east of the study area

\begin{tabular}{|c|c|c|c|}
\hline Age & Stratigraphic unit & Methods & Author \\
\hline \multicolumn{4}{|c|}{ Banded Gneissic Complex (BGC) } \\
\hline $3281 \pm 3 \mathrm{Ma}$ & Jhamarkotra Gneiss & $\mathrm{U}-\mathrm{Pb}$ zircon, ion microprobe & Wiedenbeck and Goswami (1994) \\
\hline$\sim 3530 \mathrm{Ma}$ & $\begin{array}{l}\text { Jhamarkotra gneiss, Mewar } \\
\text { Gneissic Complex }\end{array}$ & $\begin{array}{l}\mathrm{Pb} \text { isotope in zircon, evaporation } \\
\text { technique }\end{array}$ & Roy and Kröner (1996) \\
\hline $\begin{array}{l}3300 \mathrm{Ma} \\
2700 \mathrm{Ma} \\
2500 \mathrm{Ma}\end{array}$ & $\begin{array}{l}\text { TTG and enclaves, Bundhelkhand } \\
\text { massif }\end{array}$ & $\mathrm{Pb}$ isotope, ion microprobe & Mondal et al. (2002) \\
\hline $\begin{array}{l}\sim 2500 \mathrm{Ma} \\
2669 \mathrm{Ma}\end{array}$ & $\begin{array}{l}\text { Pinkish porphyritic granites and } \\
\text { TTG, Bundelkhand craton }\end{array}$ & $\mathrm{U}-\mathrm{Pb}$ zircon, LA-ICPMS & Verma et al. (2016) \\
\hline \multicolumn{4}{|c|}{ Aravalli Supergroup } \\
\hline $\begin{array}{l}2562 \pm 6 \mathrm{Ma} \\
2440 \pm 8 \mathrm{Ma}\end{array}$ & $\begin{array}{l}\text { Granitic intrusions in Aravalli } \\
\text { craton }\end{array}$ & $\begin{array}{l}{ }^{207} \mathrm{~Pb}-{ }^{206} \mathrm{~Pb} \text { zircon, ion } \\
\text { microprobe }\end{array}$ & Wiedenbeck et al. (1996) \\
\hline $1700-1900 \mathrm{Ma}$ & Jhamarkotra Formation & U-Pb zircon, LA-ICPMS & McKenzie et al. (2013) \\
\hline $1709 \pm 8 \mathrm{Ma}$ & Delwara Formation & U-Pb zircon, LA-ICPMS & McKenzie et al. (2013) \\
\hline $\begin{array}{l}2400-2600 \mathrm{Ma} \\
1700-1900 \mathrm{Ma}\end{array}$ & Aravalli Supergroup & $\begin{array}{l}\mathrm{U}-\mathrm{Pb}, \mathrm{Lu}-\mathrm{Hf}, \mathrm{O} \text { isotopes, } \\
\text { LA-ICPMS and SIMS }\end{array}$ & Wang et al. (2018) \\
\hline \multicolumn{4}{|l|}{ Delhi Supergroup } \\
\hline $\begin{array}{l}1710-1870 \mathrm{Ma} \\
2200-2500 \mathrm{Ma} \\
2700-2900 \mathrm{Ma} \\
3230-3270 \mathrm{Ma}\end{array}$ & $\begin{array}{l}\text { Alwar quartzite, North Delhi Fold } \\
\text { Belt }\end{array}$ & $\begin{array}{l}\mathrm{U}-\mathrm{Pb} \text { and } \mathrm{Lu}-\mathrm{Hf} \text { isotope of } \\
\text { zircon }\end{array}$ & Kaur et al. (2011) \\
\hline $820-920 \mathrm{Ma}$ & Sirohi Group & ${ }^{207} \mathrm{~Pb}-{ }^{206} \mathrm{~Pb}$ zircon evaporation & Purohit et al. (2012) \\
\hline \multicolumn{4}{|l|}{ Erinpura Granite } \\
\hline $\begin{array}{l}800 \pm 2 \mathrm{Ma} \\
873 \pm 3 \mathrm{Ma}\end{array}$ & $\begin{array}{l}\text { Tonalite/granodiorite basement of } \\
\text { Punagarh sediments }\end{array}$ & U-Pb zircons, TIMS & Van Lente et al. (2009) \\
\hline $\begin{array}{l}863 \pm 23 \mathrm{Ma} \\
779 \pm 16 \mathrm{Ma} \\
775 \pm 26 \mathrm{Ma} \\
736 \pm 6 \mathrm{Ma}\end{array}$ & Erinpura Granite & $\begin{array}{l}\text { CHIME Monazite } \\
{ }^{40} \mathrm{Ar}-{ }^{39} \mathrm{Ar} \text { muscovite }\end{array}$ & Just et al. (2011) \\
\hline \multicolumn{4}{|c|}{ Malani Igneous Suite } \\
\hline $745 \pm 10 \mathrm{Ma}$ & Malani Rhyolite & $\begin{array}{l}\mathrm{Rb}-\mathrm{Sr} \text { isotope dating for whole } \\
\text { rock }\end{array}$ & Crawford and Compston (1970) \\
\hline $779 \pm 10 \mathrm{Ma}$ & Malani Volcanics & $\begin{array}{l}\mathrm{Rb}-\mathrm{Sr} \text { isotope dating for whole } \\
\text { rock }\end{array}$ & Rathore et al. (1996) \\
\hline $\begin{array}{l}727 \pm 8 \mathrm{Ma} \\
698 \pm 10 \mathrm{Ma}\end{array}$ & $\begin{array}{l}\text { Jalor Granite } \\
\text { Siwana Granite }\end{array}$ & $\begin{array}{l}\mathrm{Rb}-\mathrm{Sr} \text { isotope dating for whole } \\
\text { rock }\end{array}$ & Rathore et al. (1999) \\
\hline $\begin{array}{l}761 \pm 16 \mathrm{Ma} \\
767 \pm 3 \mathrm{Ma}\end{array}$ & Sindreth Rhyolite & U-Pb zircons, TIMS & Van Lente et al. (2009) \\
\hline $753 \pm 9 \mathrm{Ma}$ & Mirpur Granite & U-Pb zircon, LA-ICPMS & De Wall et al. (2018) \\
\hline \multicolumn{4}{|c|}{ Nagar Parkar Igneous Suite } \\
\hline $\begin{array}{l}1000-1100 \mathrm{Ma} \\
900 \pm 50 \mathrm{Ma} \\
700-800 \mathrm{Ma}\end{array}$ & $\begin{array}{l}\text { Gray granite } \\
\text { Pinkish gray granite } \\
\text { Pink and reddish pink granite }\end{array}$ & U-Th- $\mathrm{Pb}$ monazite, microprobe & Khan et al. (2012) \\
\hline $\begin{array}{l}751 \pm 9 \mathrm{Ma} \\
699 \pm 26 \mathrm{Ma} \\
713 \pm 32 \mathrm{Ma}\end{array}$ & $\begin{array}{l}\text { Gray granite } \\
\text { Grayish white granite } \\
\text { Pink granite }\end{array}$ & U-Pb zircon, LA-ICPMS & Rehman et al. (2018) \\
\hline \multicolumn{4}{|c|}{ Pan-African Orogeny } \\
\hline $500-550 \mathrm{Ma}$ & Malani Volcanics & ${ }^{40} \mathrm{Ar}-{ }^{39} \mathrm{Ar}$ dating & Rathore et al. (1996) \\
\hline $450-500 \mathrm{Ma}$ & $\begin{array}{l}\text { Granite intrusions in Chail, Salkhala } \\
\text { and Haimanta, Lesser Himalaya }\end{array}$ & $\mathrm{Rb}-\mathrm{Sr}$ whole-rock isotope dating & Islam et al. (1999) \\
\hline $515 \pm 6 \mathrm{Ma}$ & $\begin{array}{l}\text { Jalor Granite - Secondary thermal } \\
\text { disturbance }\end{array}$ & ${ }^{40} \mathrm{Ar}-{ }^{39} \mathrm{Ar}$ dating & Rathore et al. (1999) \\
\hline \multicolumn{4}{|c|}{ Bhimphedian Orogeny } \\
\hline $475 \pm 6 \mathrm{Ma}$ & Peralkaline granite near Kathmandu & U-Pb zircon, SHRIMP & Cawood et al. (2007) \\
\hline $\begin{array}{l}482 \pm 8 \mathrm{Ma} \\
465 \pm 4 \mathrm{Ma}\end{array}$ & $\begin{array}{l}\text { Kyanite-grade gneiss } \\
\text { Sillimanite-grade gneiss from } \\
\text { Cambrian Tanawal Formation }\end{array}$ & U-Pb monazite, LA-ICPMS & Palin et al. (2018) \\
\hline
\end{tabular}


Click here to download e-component: Supplementary data 1.doc e-component
Click here to d

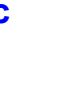


Click here to download e-component: Supplementary data 2.doc e-component
Click here to d .

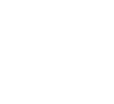
(1) (1)

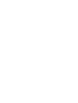
(1) (1) $\sqrt{2}$ (1) (1) (1)

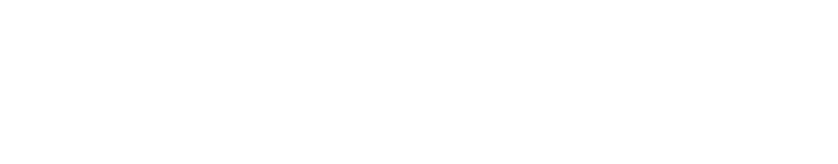
.

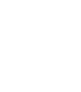

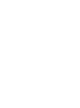
.

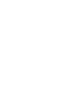

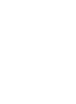

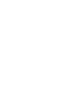

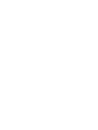

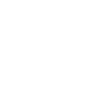

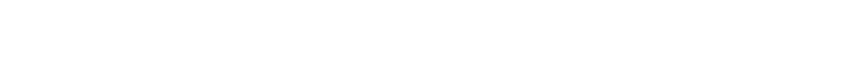

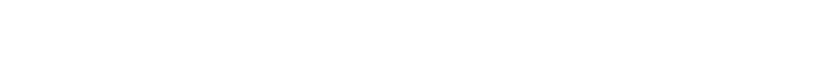

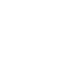

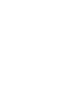

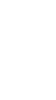

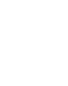

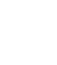
.

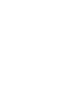

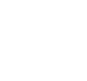

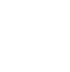

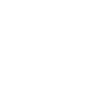

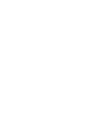
. 
Click here to download e-component: Supplementary data 3.doc e-component
Click here to d

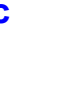

